\title{
The Challenges of Applying the Ecosystem Approach to Spatial Planning in the EEZ: German Experiences
}

\author{
Eva Schachtner
}

The German coastline has a total length of approximately 3,402 km; the North Sea Coast is $1,155 \mathrm{~km}$ long and the Baltic Sea Coast is 2,247 km long. ${ }^{1}$ Lagoons, estuaries, bays, mudflats, peninsulas, islands, cliffs and flat coastal plains form a beautiful and diverse coastal landscape. Whereas tidal movement is significant on the North Sea coast, this phenomenon is barely noticeable in the brackish Baltic Sea. ${ }^{2}$ The North Sea is one of the most productive and biologically diverse seas of the world. The Wadden Sea, the world's largest ecosystem of its kind, with a total surface of 8,00o $\mathrm{km}^{2}$, serves as a nursery for many fish species, as a stepping stone for migrating birds, and as a breeding and moulting area. The Baltic Sea, in contrast, is characterized by a low diversity of species, caused by its isolation from the North Sea and its low oxygen content and salinity.

Several large cities are located along the coast, including Hamburg, Kiel and Rostock. Outside the cities, the region has a relatively low population density. ${ }^{3}$ The three largest German ports are in Hamburg, Bremerhaven and Wilhelmshaven. ${ }^{4}$ The North Sea and the Baltic Sea are among the most heavily

1 EUCC - Die Küstenunion Deutschland e.V., 'Die Ostseeküste' <www.ikzm-d.de/inhalt .php?page=151,3494> accessed 30 September 2018 .

2 Gerald Schernewski, 'Integrated Coastal Zone Management (ICZM): From European strategy to practice in Germany' (2002) European Union for Coastal Conservation (EUCC) <http://eucc-d-inline.databases.eucc-d.de/files/documents/ooooo68o_Schernewski_ICZM_ Germany.pdf>.

3 Bundeszentrale für politische Bildung, 'Siedlungsstruktur und Bevölkerungsdichte' <www .bpb.de/nachschlagen/datenreport-2016/226681/siedlungsstruktur-und-bevoelkerungs dichte> accessed 30 September 2018.

4 Statista, 'Top 10 Seehäfen in Deutschland' <https:/de.statista.com/statistik/daten/ studie/239221/umfrage/groesste-haefen-in-deutschland-nach-gueterumschlag/> accessed 30 September 2018.

(C) EVA SCHACHTNER, 2019 | DOI:10.1163/9789004389984_012

This is an open access chapter distributed under the terms of the prevailing CC-BY-NC License at the time of publication. 
navigated seas of the world. ${ }^{5}$ Particularly in the summer, the German coast is a popular tourist destination with about 6.8 million tourists spending their holidays at the Baltic Sea coast in 2018. ${ }^{6}$ In addition, to implement the energy transition towards renewable energies, 1,196 offshore wind turbines have been installed in the German marine areas as of the end of 2017. ${ }^{7}$ Activities in the coastal and marine zone further include dredging and the extraction of gravel and sand, petroleum and natural gas exploration, laying of pipelines and cables, fisheries, aquaculture, agriculture, construction of coastal protection measures, and military activities. ${ }^{8}$

For a long time, no need was seen in Germany to coordinate the traditional maritime uses by means of spatial planning. This changed at the end of the 1990 due to ongoing technical and economic development and the resulting user conflicts. ${ }^{9}$ In particular, the planning of offshore wind farms, as well as the extension of the Federal Nature Conservation Act $^{10}$ to the Exclusive Economic Zone (EEZ), and the subsequent possibility of designating protected areas in the EEZ, intensified the competition for marine space. The 'first come, first served' principle that had dominated the allocation of marine space was no longer considered adequate to balance the various interests. ${ }^{11}$ Rather, it was decided that, just as in the terrestrial context, user-user conflicts as well as user-environment conflicts should be comprehensively addressed in the marine area through a process of marine spatial planning. A revision of

$5 \quad$ Federal Ministry for the Environment, Natures Conservation and Nuclear Safety, Nationale Strategie für ein integriertes Küstenzonenmanagement (Cabinet Decision of 22 March 2006) 20.

6 Statista, 'Anzahl der Personen in Deutschland, die in den vergangenen 12 Monaten an die Ostsee in den Urlaub gefahren sind' <https:/de.statista.com/statistik/daten/ studie/173279/umfrage/beliebte-reiseziele---anzahl-der-ostseeurlauber/> accessed 30 September 2018.

7 BWE (Bundesverband WindEnergie), 'Offshore' <www.wind-energie.de/themen/ offshore > accessed 30 September 2018.

8 Gerald Schernewski, 'Integrated Coastal Zone Management (ICZM): From European strategy to practice in Germany' (2002) European Union for Coastal Conservation (EUCC) $<$ http://eucc-d-inline.databases.eucc-d.de/files/documents/ooooo68o_Schernewski_ ICZM_Germany.pdf >.

9 Helmuth von Nicolai, 'Rechtliche Aspekte einer Raumordnung auf dem Meer', (2004) 7/8 Informationen zur Raumentwicklung 491, 491.

10 Federal Nature Conservation Act of 29 July 2009 (Federal Law Gazette, Part I, No 51/2542), last amended by the Act of 15 September 2017 (Federal Law Gazette, Part I, No 64/3434).

11 Peter Ehlers, 'Nutzungsregime in der Ausschließlichen Wirtschaftszone' in Peter Ehlers and Wilfried Erbguth (eds), Nutzungs- und Schutzkonflikte in der Ausschließlichen Wirtschaftszone (Nomos 2005) 13, 29. 
the Federal Spatial Planning Act (FSPA) in 2004 facilitated the establishment of spatial plans for the EEZ. Based on the FSPA, legal ordinances concerning the spatial plans for the German Eez in the North Sea and the Baltic Sea were prepared by the Federal Maritime and Hydrographic Agency (BSH) and adopted by the Federal Ministry of Transport, Building and Urban Development (BMVBS). They entered into force in 2009. ${ }^{12}$

In these spatial plans, the вмVвs, which became the Federal Ministry of Transport and Digital Infrastructure (BMVI) in December 2013, formulated guidelines for spatial development (chapter 2) and set targets and principles for functions and uses (chapter 3 ). The spatial plans contain provisions aimed at coordinating shipping and regulating the exploitation of resources, the laying of pipelines and submarine cables, scientific marine research, wind power generation, fisheries and mariculture, as well as the protection of the marine environment. Each provision is followed by a justification of the scientific and legal reasons for its incorporation in the plan. Chapter 4 of the plans deals with further relevant interests. Chapter 5 describes the manner in which the results of the environmental assessment of the plans, which has been carried out in parallel with the planning process, have been taken into consideration. Finally, chapter 6 contains the coordinates corresponding to the regulations and maps depicting transnational pipelines and cables.

The FSPA was amended in 2017 to implement Directive 2014/89/EU establishing a framework for maritime spatial planning (MSP-Directive). ${ }^{13}$ Among other amendments, the Act now requires the sustainable development of the marine area to be supported by the application of the ecosystem approach. ${ }^{14}$ By taking the full array of interactions among ecosystem components and human uses into consideration, it is anticipated that the ecosystem approach can help to better arbitrate between the increasing diversity and intensity of human activities and the protection of marine ecosystems. As a consequence of the

12 Spatial Plan for the Baltic Sea (Annex to Federal Law Gazette, Part I, No 78 of 18 December 2009); Spatial Plan for the North Sea (Annex to Federal Law Gazette, Part I, No 61 of 25 September 2009). An English version of the Spatial Plans for the North Sea and the Baltic Sea as well as of the respective Environmental Reports is planned to be available in the future under the following link: <www.bsh.de/EN/TOPICS/Offshore/offshore node.html $>$. The numbering of sections in the text refers to the Spatial Plan for the North Sea to exemplarily illustrate the spatial planning measures taken in the EEZ, but the regulations in the Spatial Plan for the Baltic Sea are quite similar.

13 Directive 2014/89/EU of the European Parliament and of the Council establishing a framework for maritime spatial planning [2014] OJ L 257/135 (MSP-Directive).

14 Section 2 para. 2 no. 6 FSPA (in implementation of Art. 5 para. 1 MSP-Directive). 
amendments to the FSPA, which entered into force on 29 November $2017,{ }^{15} \mathrm{a}$ review and revision of the spatial plans for the German EEZ is expected.

The present study examines the extent to which the German legal provisions for marine spatial planning in the FSPA and the spatial plans adopted for the EEZ correspond to the requirements of the ecosystem approach. Furthermore, it examines whether the regulations of the FSPA provide for the possibility of an even better protection of marine ecosystems in the second generation of plans, which seems to be the ultimate goal of the ecosystem approach. The focus of the analysis will be on whether the German spatial planning tools are flexible enough to reflect the characteristics of ecosystems, and on what components could help to improve ecosystem protection in marine spatial planning.

\section{$2 \quad$ Planning Tools in Germany}

The FSPA sets out the framework for spatial planning in Germany. It contains regulations concerning the distribution of competences between the federal government and the federal states, the planning process including the environmental assessment of the draft spatial plans and the preparation of the environmental reports, as well as basic content requirements. Section 1 para. 1 of the FSPA specifies the task of spatial planning. According to this section, the territory of the Federal Republic of Germany shall be developed, organized and protected through integrated general regional plans, cooperation and the harmonization of regionally significant plans and measures. Different spatial demands on an area shall be coordinated and conflicts resolved. The definition of the function of spatial planning sets a limit to the possibility of making detailed sectoral regulations at the planning level. Spatial planning is to be concerned only with the reconciliation of the various spatial demands and the prevention and resolution of conflicts emerging at that level, ${ }^{16}$ and not with replacing sectoral decisions. ${ }^{17}$ However, the transition between sectoral and comprehensive spatial planning seems to be rather fluid. ${ }^{18}$

\footnotetext{
15 Federal Spatial Planning Act of 22 December 2008 (Federal Law Gazette, Part I, No 65/ 2986), last amended by the Act of 23 May 2017 (Federal Law Gazette, Part I, No 30/1245).

16 Cf. Section 1 para. 1 no. 1 FSPA.

17 Martin Kment, 'Standortfestlegungen und Streckenverläufe - Neues zum Verhältnis von Raumordnung und Fachplanung' (Issue 6, 2010) 32 Natur und Recht 392, 392-393.

18 Bernhard Stüer and Dietmar Hönig, 'Raumordnung und Fachplanung im Widerstreit' in Jan Ziekow (ed), Bewertung von Fluglärm - Regionalplanung - Planfeststellungsverfahren (Duncker \& Humblot 2003) 225, 225.
} 
The main tools of spatial planning articulated in the legislation are targets and principles. Targets, within the meaning of the FSPA, are binding stipulations in textual or graphical form in a spatial plan with a clear content and a clear geographical scope of application concerning the development, organization and protection of a certain area. ${ }^{19} \mathrm{~A}$ conclusive weighing of all relevant interests constitutes a prerequisite for their binding effect. With the determination of a target, a final decision in respect of a spatial conflict has to be taken. ${ }^{20}$ Principles are, in contrast, guidelines for two types of subsequent decisions, decisions requiring a balancing of interests and concerns and discretionary decisions. Often, several principles have to be balanced against each other. ${ }^{21}$ They can be set in a law or in a spatial plan. ${ }^{22}$ Targets have to be observed by public authorities with regard to their plans and measures of spatial relevance, but particularly with regard to their decisions concerning licensing procedures and the approval of projects. The approval authority generally has to reject development applications if the spatial plan contains targets that oppose the development. Principles only have to be taken into consideration. ${ }^{23}$

The FSPA provides, moreover, for the possibility of establishing priority areas, reserve areas and suitability areas. ${ }^{24}$ A priority area (considered a 'target') is an area intended for certain regionally significant functions or uses, in which other regionally significant uses are excluded insofar as they are incompatible with the priority functions or uses. ${ }^{25} \mathrm{~A}$ reserve area (considered a 'principle') is an area where special importance is attached to certain regionally significant functions or uses when weighted against competing regionally significant uses. ${ }^{26}$ In a spatial plan, suitability areas can also be indicated for the marine area. These are areas that are considered especially suited for certain uses or functions. The designation of suitability areas entails the exclusion of the respective uses or functions from other parts of the planning area. ${ }^{27} \mathrm{An}$ overlapping of different categories of areas is difficult because of the problem

\footnotetext{
19 Section 3 para. 1 no. 2 FSPA.

20 Hans-Joachim Koch and Reinhard Hendler, Baurecht, Raumordnungs- und Landesplanungsrecht (Boorberg, 2015) 57.

21 Dressler and others, Weiterentwicklung der Landschaftsrahmenplanung und ihre Integration in die Regionalplanung (Landwirtschaftsverlag 2000) 29 Angewandte Landschaftsökologie 132.

22 Section 3 para. 1 no. 3 FSPA.

23 Section 4 para. 1 FSPA.

24 Section 7 para. 3 FSPA.

25 Section 7 para. 3 no. 1 FSPA.

26 Section 7 para. 3 no. 2 FSPA.

27 Section 7 para. 3 no. 4 FSPA.
} 
of conflicting priorities. ${ }^{28}$ In such cases it will be necessary to ensure that, because of the purpose of the respective areas, conflicts are excluded or that conflict rules are defined in the plan. ${ }^{29}$

\section{3}

\section{The Ecosystem Approach}

There is no universal definition of the ecosystem approach. Within the scope of the Convention on Biological Diversity, the ecosystem approach is defined as 'a strategy for the integrated management of land, water and living resources that promotes conservation and sustainable use in an equitable way'. ${ }^{30}$ According to the definition adopted by $\mathrm{HELCOM}^{31}$ and OSPAR, ${ }^{32}$ the ecosystem approach is 'the comprehensive integrated management of human activities based on the best available scientific knowledge about the ecosystem and its dynamics, in order to identify and take action on influences which are critical to the health of marine ecosystems, thereby achieving sustainable use of ecosystem goods and services and maintenance of ecosystem integrity'. ${ }^{33}$ Recital 14 of the MSP-Directive states that the ecosystem approach shall aim at 'ensuring that the collective pressure of all activities is kept within levels compatible with the achievement of good environmental status and that the capacity of marine ecosystems to respond to human-induced changes is not compromised, while contributing to the sustainable use of marine goods and services by present and future generations'.

28 Federal State Parliament of Mecklenburg-Western Pomerania (document: Drucksache 6/3237 of 30 September 2014) 1 .

29 Example of a conflict rule: 'When designations of priority areas for pipelines overlap with priority areas for wind energy, the requirements of the pipelines shall be given priority.' (Target 3 in Section 3.3 on pipelines and submarine cables).

30 Convention on Biological Diversity, 'Ecosystem Approach' <www.cbd.int/ecosystem/> accessed 30 September 2018.

31 The Baltic Marine Environment Protection Commission (the Helsinki Commission HeLCOM). HeLCOM is the governing body of the Convention on the Protection of the Marine Environment of the Baltic Sea Area, known as the Helsinki Convention, 1507 UNTS 167; 1994 OJ (L 73) 20; 13 ILM 546 (1974).

32 The ospar Commission for the Protection of the Marine Environment of the North East Atlantic (OSPAR). The OSPAR Commission is the governing body of the Convention for the Protection of the Marine Environment of the North-East Atlantic, known as the OSPAR Convention, 2354 UNTS 67; 32 ILM 1069 (1993).

33 helcom / ospar Commission for the Protection of the Marine Environment of the North East Atlantic, Statement, Towards an Ecosystem Approach to the Management of Human Activities (First Joint Ministerial Meeting of the HELSINKI and OSPAR Commissions, 2003) Point 5. 
Despite the importance given to the ecosystem approach at the international level, the precise content of the approach still appears nebulous, rendering it difficult to put into practice. ${ }^{34}$ Including the ecosystem approach in the spatial planning process is considered to help make the approach operational in the marine environment. ${ }^{35}$ Through the formulation of 'key elements for applying the ecosystem-based approach in MSP', described in the 2016 Guideline for the implementation of ecosystem-based approach in Maritime Spatial Planning (MSP) in the Baltic Sea area (EBA-Guideline), ${ }^{36}$ HELCOM and Vision and Strategies around the Baltic Sea (VASAB) ${ }^{37}$ attempt to clarify the requirements of the concept. The key elements comprise: best available knowledge and practice; precaution; alternative development; identification of ecosystem services; mitigation; relational understanding; participation and communication; subsidiarity and coherence; as well as adaptation. Since the EвAGuideline represents one of the most recent and most widely accepted compilations of elements of the ecosystem approach, those key elements will constitute the points of reference in the following analysis of the German progress on implementing the ecosystem approach. ${ }^{38}$ This method does not imply that there is a one-size-fits-all solution for the application of an ecosystem approach to marine spatial planning. Rather, the appropriate range of tools and methods varies according to the scenarios of the respective plan area. ${ }^{39}$ The specification of the requirements of the ecosystem approach tailored to the legal and administrative system in Germany as well as to the conditions in the German EEZ is therefore currently the subject of several research projects.

34 Rafael Sardá and others, 'Ecosystem-Based Management for Marine Protected Areas: A Systematic Approach' in Paul Goriup (ed), Management of Marine Protected Areas: A Network Perspective (Wiley-Blackwell, 2017) 145, 146.

35 Fanny Douvere, 'The importance of marine spatial planning in advancing ecosystembased sea use management' (2008) 32 Marine Policy 762, 765 .

36 нецсом, Heads of Delegation, Guideline for the implementation of ecosystem-based approach in Maritime Spatial Planning (MSP) in the Baltic Sea area (EBA-Guideline) (HOD 50-2016).

37 Intergovernmental multilateral co-operation of 11 countries of the Baltic Sea Region in spatial planning and development.

38 The key elements in the EBA-Guideline seem to widely correspond to the key principles that have been identified to be included in most of the definitions describing marine ecosystem-based management: Cf. Rachel D Long, Anthony Charles and Robert L Stephenson, 'Key principles of marine ecosystem-based management' (2015) 57 Marine Policy 53-6o.

39 Scottish Natural Heritage, 'An ecosystem approach to marine planning - a summary of selected tools, examples \& guidance' (2016) <www.nature.scot/sites/default/files/2017 -06/2016\%2005\%2018\%20-\%2oEcosystem\%2oapproach\%2oin\%2omarine $\% 20$ planning\%20-\%2oFINAL\%2oVersion\%201.pdf>1. 


\section{Key Elements of the Ecosystem Approach in Marine Spatial Planning and Their Implementation in the German EEZ}

\subsection{Best Available Knowledge and Practice}

To implement the ecosystem approach, the allocation and development of human uses shall, pursuant to the EBA-Guideline, be based on the latest state of knowledge of the ecosystems as such and the practice of safeguarding the components of the marine ecosystem in the best possible way. The MSPDirective also requires the use of the best available data. ${ }^{40}$ The legal framework for the transposition of this requirement into German law is formed, according to the explanatory statement to the draft amendment to the FSPA, ${ }^{41}$ by Section 7 para. 2 of the FSPA, as well as by the respective Sections on strategic environmental assessment, the information obligation, and on participation. ${ }^{42}$ Section 7 para. 2 of the FSPA states that relevant public and private interests shall be duly weighed and fairly balanced in the planning process insofar as they are apparent and sufficiently important at the respective planning level. The duty to duly consider all interests implies the duty to gather information on all potentially relevant interests. The best available data must be determined in each individual case and the planning authority has some margin of discretion in that regard. ${ }^{43}$ Other public authorities shall be asked to provide information on their envisaged plans and measures and other information available to them, ${ }^{44}$ but they are not obliged to investigate additional facts. ${ }^{45}$ Within the environmental assessment, the impacts of the plan on the marine environment then have to be comprehensively investigated. This obligation is, however, softened by stating that the depth of the examination may be limited to what can be reasonably expected with regard to the current state of knowledge. ${ }^{46}$ Even though neither the MSP-Directive nor the EBAGuideline require the conduct of additional research on ecosystem functioning, it seems questionable whether the reluctance to require further research

\footnotetext{
40 Directive 2014/89/EU, Art. 10 para. 1.

41 Deutscher Bundestag, Draft Act amending the Federal Spatial Planning Act (document: Drucksache 18/10883, 2017) 42.

42 Section 8 para. 1 , Section 9 para. 1 and Section 9 para. 2 and 3 FSPA.

43 Deutscher Bundestag, Draft Act amending the Federal Spatial Planning Act (document: Drucksache 18/10883, 2017) 42.

44 Section 9 para. 1 FSPA.

45 Deutscher Bundestag, Draft Act amending the Federal Spatial Planning Act (document: Drucksache 18/10883, 2017) 47.

46 Section 8 para. 1 FSPA.
} 
in the preparation of the plans does justice to the importance of a comprehensive information base for ecosystem protection.

Further details concerning the gathering of information and the use of data are specified in the spatial plans themselves. Thus, for a comprehensive and large-scale gathering of knowledge regarding ecosystem interrelationships, the results of marine scientific research should be continuously collected (Principle 3 in Section 3.4.1 on marine scientific research). According to the justification for this principle, this knowledge is to be used to monitor the effects of the implementation of the marine spatial plan. The principle is based on the recognition that a sufficient state of knowledge is a prerequisite for the sustainable development of the EEZ and the ongoing improvement of the plans.

With respect to individual uses, specific provisions are made with a view to learning more about their impacts on the marine ecosystem. For example, Target 4 in Section 3.5.1 on energy production states that a 'reference area' is to be kept free of wind energy installations in order to facilitate a comparative analysis. Another example is Principle 9 in Section 3.2.1 on the exploitation of non-living resources that requires that the effects of resource exploitation on the marine environment are examined through project-specific monitoring. The definition of the concrete requirements of this examination is delegated to the approval authority. The plans themselves thus provide for the incremental improvement of knowledge concerning ecosystem functioning that can then be used to improve the next generation of spatial plans. Such an approach can help to reconcile the necessity of generating an adequate information base crucial for ecosystem-based spatial planning with the necessity of a timely adoption of the plans.

\subsection{Precaution}

Far less is known about marine than about terrestrial ecosystems. In addition, marine ecosystems exhibit complex system behaviours and it can therefore not be safely assumed that they recover when stressors are reduced. ${ }^{47}$ Thus, the application of precaution is particularly important to ensure a careful and responsible use of the marine area. ${ }^{48}$ With regard to precaution, the EBAGuideline states that far-sighted, anticipatory and preventive planning shall promote sustainable use in marine areas and shall exclude risks and hazards of human activities on the marine ecosystem. However, while requiring a specific careful survey and weighting of the risks of those activities that according to

47 Larry Crowder and Elliott Norse, 'Essential ecological insights for marine ecosystembased management and marine spatial planning' (2008) 32 Marine Policy 772, $77^{2}$.

48 Cf. Guideline 2.5 of the spatial plan. 
current scientific knowledge may lead to significant or irreversible impacts on the marine ecosystem and whose impacts may not be in total or in parts sufficiently predictable at present, the EBA-Guideline does not require the avoidance of any risk.

According to the FSPA (Section 1 para. 1), spatial plans have to provide both for uses in and for the functions of an area, including the functions of ecosystems, but the planning authority has a certain leeway with regard to the appropriate level of precaution. ${ }^{49}$ The same applies for the balancing of interests according to Section 7 para. 2 of the FSPA. Moreover, the principle of proportionality sets limits to the application of precaution. Implementing precaution in marine spatial planning thus involves, pursuant to the FSPA, value judgments and trade-offs between competing spatial demands. In particular, the FSPA has been criticised on the basis that no principal priority in the process of weighing up the planning options has been given to environmental concerns in the face of uncertainty. The application of the precautionary principle under the FSPA therefore often takes the form of mere hazard prevention rather than ensuring an increase in environmental quality. ${ }^{50}$ If precaution is understood as requiring consideration and some sort of balancing of all risks, ${ }^{51}$ the provisions of the FSPA nevertheless seem to meet the respective requirements of the ecosystem approach.

The conditions for the determination of the different spatial planning instruments further influence the level of precaution that can be ensured by the spatial plans. A conclusive weighing of interests is a prerequisite for the establishment of binding spatial planning targets, including the establishment of priority areas. ${ }^{52}$ If such a conclusive weighing is not possible due to a knowledge deficit with respect to the detrimental impacts of a certain anthropogenic activity on the marine environment, then, in line with the precautionary principle, it is not possible to establish targets or a priority area favouring this activity. ${ }^{53}$ Because of the impossibility of clearly defining areas of special importance to benthic communities, however, it has also been considered

49 Cf. Niedersächsisches ovg (higher administrative court of Lower Saxony), decision of 28 October 2004, case number $1 \mathrm{KN}$ 155/03 para 68.

5o Wilfried Kühling, Christian Hildmann, 'Umweltziele koordinieren und verbindlich machen' (2003) 107 RaumPlanung 62, 63.

$5^{1}$ Rosie Cooney, 'The Precautionary Principle in Biodiversity Conservation and Natural Resource Management' IUCN Policy and Global Change Series no 2 (2004) 28.

$5^{2}$ Section 3 para. 1 no. 2 FSPA.

53 Johann Köppel, Wolfgang Wende and Alfred Herberg, 'Naturschutzfachliche und naturschutzrechtliche Anforderungen im Gefolge der Ausdehnung des Raumordnungsregimes auf die deutsche Ausschließliche Wirtschaftszone' (2006) Schriften des Bundesamtes für Naturschutz 82 . 
impossible to designate areas ensuring their protection at the time of the adoption of the current spatial plans. ${ }^{54}$

Since the establishment of spatial planning targets is subject to strict conditions, the provisions of the German plans often have recourse to the 'weaker' technique of simply determining principles to deal with uncertainty regarding the marine environment. For example, with regard to the laying and operation of pipelines and submarine cables, Principle 8 in Section 3.3.1 says that any damage to or destruction of sandbanks, reefs, or other areas with valuable benthic communities shall be avoided, including in such areas that are outside Natura 2000 sites. ${ }^{55}$ At the time the Principle was adopted it was not possible to identify the concrete locations of those structures. If they are found in the course of the procedure for the approval of pipelines and submarine cables, the Principle at least ensures that consideration is given to their protection in the decision-making process. ${ }^{56}$ That means that the plan makes provisions for the protection of particularly sensitive habitats, by, at the same time, facilitating a case-by-case decision of the approving authority.

Of course, as long as any anthropogenic activities are permitted, the application of precaution can always be improved. However, a 'zero risk' approach does not seem feasible considering the economic importance of maritime uses. The relevant question is, therefore, whether an appropriate balance between protection and use has been achieved in the spatial plans in Germany. From a nature conservation perspective, it has to be emphasized that even the spatial demands of species and ecosystems that were substantiated in the planning contribution of the Federal Agency for Nature Protection were not adequately taken into account in the plans of 2009. ${ }^{57}$ Nevertheless, the environmental report states that enforcing the determinations of the spatial plan will not impact the marine environment in a significant way.

The development of criteria for the application of the precautionary principle in regulating sea uses through marine spatial planning would certainly help to clarify the requirements of the precautionary principle on the evaluation of

54 Federal Maritime and Hydrographic Agency, Non-technical summary of the Environmental Report for the North Sea, Section 9.7.1.

55 Natura 2000 sites are designated to protect core areas for species or habitat types listed in the Habitats Directive (92/43/EEC) and the Birds Directive (2009/147/EC).

56 Cf. justification to Principle 8.

57 Cf. the recommendations in the planning contribution of the Federal Agency for Nature Conservation, Naturschutzfachlicher Planungsbeitrag des Bundesamtes für Naturschutz zur Aufstellung von Zielen und Grundsätzen der Raumordnung für die deutsche Ausschließliche Wirtschaftszone der Nord- und Ostsee (2006) available online at <www.bfn .de/fileadmin/MDB/documents/themen/landschaftsplanung/Planungsbeitrag_zur_ Raumordnung_AWZ_20o6.pdf >. 
risks. ${ }^{58}$ In this respect, the German 'Standard Investigation of the Impacts of Offshore Wind Turbines on the Marine Environment (StUK4), 59 a standard method prepared to facilitate and harmonize the environmental impact assessment for wind energy projects, could serve as an example. Respective criteria would also help to avoid the danger of the obligations imposed on the planning authority by the requirements of the precautionary principle to reasonably demonstrate that plans will not cause harm to the environment ${ }^{60}$ becoming 'open-ended'. ${ }^{61}$

\subsection{Alternative Development}

Not all conflicts can be 'planned away' through marine spatial planning. ${ }^{62} \mathrm{How}-$ ever, by examining alternative forms of spatial development, the least environmentally harmful option can be identified. For this reason, the EBA-Guideline requires that reasonable alternatives shall be developed to find solutions to avoid or reduce negative environmental and other impacts, as well as impacts on the ecosystem goods and services. Considering alternative siting, for example, helps to protect migration routes and areas of retreat for endangered species and to minimize fragmentation effects. ${ }^{63}$ In the German spatial plans, care has been taken, based on 'the available findings on the migratory behavioural patterns of various bird species, the customary flight altitudes and the daytime distribution of bird migrations', to ensure that the majority of migratory birds

58 Baltic SCOPE, 'Recommendations on Maritime Spatial Planning Across Borders' (2017) Recommendation No. 5 on environment $<$ www.balticscope.eu/content/uploads/2015/07/ BalticScope_OverallRecomendations_EN_WWW.pdf>.

59 Federal Maritime and Hydrographic Agency, Standard Investigation of the Impacts of Offshore Wind Turbines on the Marine Environment (StUK4) (2013) <www.bsh.de/ DE/PUBLIKATIONEN/_Anlagen/Downloads/Offshore/Standards-EN/Standard -Investigation-impacts-offshore-wind-turbines-marine-environment.pdf?__blob $=$ publicationFile $\& \mathrm{v}=4>$.

6o Cf. John Quiggin, 'Complexity, climate change and the precautionary principle' (2007) 7(3) Environmental Health 15, 21.

61 Henk van den Belt, 'Debating the Precautionary Principle: "Guilty until Proven Innocent" or “Innocent until Proven Guilty"?' (2003) 132 Plant Physiol. 1122, 1125.

62 Wanfei Qiu and Peter JS Jones, 'The emerging policy landscape for marine spatial planning in Europe' (2003) 39 Marine Policy 182, 188.

63 Federal Agency for Nature Conservation, Naturschutzfachlicher Planungsbeitrag des Bundesamtes für Naturschutz zur Aufstellung von Zielen und Grundsätzen der Raumordnung für die deutsche Ausschließliche Wirtschaftszone der Nord-und Ostsee (2006) 14 available online at <www.bfn.de/fileadmin/MDB/documents/themen/landschaftsplanung/ Planungsbeitrag_zur_Raumordnung_AWZ_20o6.pdf >. 
will not be affected by the wind energy projects in the designated priority areas for wind energy generation. ${ }^{64}$

Since the need for protection of species may also vary over time, alternative time-frames have to be taken into consideration in the regulation of certain uses. For example, Section 3.3.1 on pipelines and submarine cables states that, to minimize possible negative impacts on the marine environment when laying pipelines and submarine cables, sensitive habitats should not be crossed during periods of high vulnerability of particular species (Principle 8). The task of determining such periods is then shifted to the approval level. ${ }^{65} \mathrm{In}$ addition, Principle 13 in Section 3.3.1 on pipelines and submarine cables stipulates that, to avoid and/or minimize any cumulative effects, all time schedules for the laying of submarine cables for the transport of power generated in the EEZ should be coordinated. This temporal coordination, which necessarily includes the examination of different alternatives, can help to reduce the number of disruptive interventions or, through the staggering of activities, ensure adequate periods of low use, or no use, which are crucial for the regeneration of the environment.

The plans furthermore provide specifications for the choice between alternatives, especially alternative technologies, at the approval level. Thus, according to Target 5 (Section 3.3.1) of the spatial plan, after termination of use, pipelines and submarine cables shall be dismantled. If dismantling would cause greater environmental harm than leaving them in place, the dismantling requirement may be waived wholly or in part, unless dismantling is required to ensure the safety and efficiency of navigation. Therefore, the anticipated conflicts with regard to the protection of the marine environment are conclusively regulated by making clear specifications for the choice of the right alternative at the approval level. The appropriate provisions for dismantling are then to be specified within the individual approval procedures. ${ }^{66}$ The justification for Principle 12 (Section 3.3.1) on the selection of the burial depth of submarine cables for the transport of power generated in the EEZ enumerates the various needs that must be weighed against each other when choosing the most appropriate alternative. On the one hand, deeper cable burial reduces the risk of damage and helps to limit an increase in temperature in the sediment and to reduce the effects of electromagnetic fields. On the other hand, increased

\footnotetext{
64 Federal Maritime and Hydrographic Agency, Non-technical summary of the Environmental Report for the North Sea 53.

65 Cf. justification to Principle 8.

66 Cf. justification to Principle 5.
} 
burial depths lead to increased structural engineering expenditures. Instead of deciding on the optimal balance between these needs itself, here again the planning authority leaves the final choice of the right alternative to the approval authority. Even though it has to be recognized that the circumstances of each individual case cannot be fully anticipated at the planning level, by extensively delegating decisions to the approval level, the planning authority does not seem to make the fullest possible use of its possibilities to regulate uses to the benefit of the protection of the marine environment.

It is difficult to trace whether, and if so to what extent, further planning alternatives have been considered in the German planning process. According to the FSPA, the environmental report must contain information on appropriate planning alternatives having regard to the objectives and the geographical scope of the plan. ${ }^{67}$ In the environmental reports that have been prepared during the planning process, the focus has been placed on assessing the development in the event that the plan is not implemented at all, rather than on assessing reasonable and potentially less harmful alternatives. ${ }^{68}$ Thus, when compared to the future development of the EEZ in the absence of the implementation of the spatial plan, positive impacts on the environment can be expected simply on account of the co-ordinating and concentrating effects of the spatial planning determinations. It is therefore questionable whether the current planning stipulations actually represent the best environmental alternatives.

\subsection{Identification of Ecosystem Services}

According to the EBA-Guideline, the ecosystem services provided must be identified, in order to ensure a socio-economic evaluation of effects and potentials. The FSPA does not contain an explicit requirement to identify ecosystem services in the planning process, but maintaining ecosystem services does form part of the private and public interests that have to be considered in the planning process according to Section 7 para. 2 of the FSPA.

Ecosystem services represent ecological processes and resources expressed in terms of the goods and services they provide to society. In order for an ecosystem to provide services to humans, there needs thus to be some appreciation

\footnotetext{
$67 \quad$ Annex 1 no. 2 lit. $d$ to Section 8 para. 1.

68 Cf., for example, Federal Maritime and Hydrographic Agency, Non-technical summary of the Environmental Report for the North Sea, Sections 9.3.8.2 and 9.7.1.
} 
of them. ${ }^{69}$ The requirement to identify ecosystem services in the context of implementing the ecosystem approach seems to be based on the recognition that not only anthropogenic impacts shape the environment, but that environmental changes also have an impact on humans and their activities ${ }^{70}$ and that humans are 'an integral component of ecosystems..$^{71}$

The persuasive power of revealing the benefits of ecosystem services and the respective support for the promotion of nature protection within spatial planning should not be underestimated. Nevertheless, in this regard, 'caution needs to be taken with the assumptions needed to convert natural benefits into financial currency and also because monetary assessments could be considered to compound the materialistic values of society rather than directly address the need for a deeper social shift in valuing environment and sustainability. ${ }^{72}$ Even ecosystem processes that presumably provide no direct service to humans have to be maintained, both because of the intrinsic value of ecosystems and because of the still incomplete understanding of ecosystem functioning. In this spirit, Section 1 para. 1 Nature Conservation Act requires that nature and landscape are protected by virtue of their intrinsic value and importance as a basic necessity of human life, and also as a responsibility to future generations. Therefore, economic valuations should only constitute a complementary element in the process of balancing the relevant interests ${ }^{73}$ and not a decisive criterion for planning decisions.

If ecosystem services are understood in a broader sense, according to which almost every known ecosystem process delivers ecosystem services to humans, their identification and preservation can certainly contribute to comprehensive ecosystem protection. For example, the indicators for ecosystem services delivered by marine ecosystems that have been developed by the Biodiversity Information Service System for Europe, include rather general indicators such

69 European Commission, DG Environment, The Multifunctionality of Green Infrastructure (2012) Science for Environment Policy $13<$ http://ec.europa.eu/environment/nature/ ecosystems/docs/Green_Infrastructure.pdf $>$.

70 Elizabeth M De Santo, 'Environmental justice implications of Maritime Spatial Planning in the European Union' (2011) 35 Marine Policy 34, 34.

71 Convention on Biological Diversity, 'Ecosystem Approach' <www.cbd.int/ecosystem/> accessed 30 September 2018.

72 European Commission, DG Environment, The Multifunctionality of Green Infrastructure (2012) Science for Environment Policy $30<\mathrm{http}: / /$ ec.europa.eu/environment/nature/ ecosystems/docs/Green_Infrastructure.pdf $>$.

73 Detlef Czybulka, 'Der Ökosystemansatz als Managementprinzip des Naturschutzes', in Lothar Knopp and Heinrich Amadeus Wolff (eds), Umwelt - Hochschule - Staat: Festschrift für Franz-Joseph Peine zum 7o. Geburtstag (Duncker \& Humblot 2016) 21, 31. 
as the extent of marine protected areas and the presence of iconic/endangered species representing services ranging from hydrological cycle maintenance to global climate regulation. ${ }^{74}$ Moreover, the value of ecosystem services for humans has been considered to include non-use values that 'stem from people's knowledge that nature exists ('existence value') or because they wish it to exist for future generations ('bequest value') or for others in present generations ('altruist value') ${ }^{75}$

\subsection{Mitigation}

The EBA-Guideline requires that measures are envisaged to prevent, reduce and as fully as possible offset any significant adverse effects on the environment of implementing the plan. As in other countries, in Germany, there are several regulatory levels that collectively aim to ensure appropriate mitigation of and compensation for the adverse effects on the environment of projects, activities, plans and programmes. The comprehensive perspective of the planning level appears to be the most appropriate level at which to take all the interrelationships of ecosystem components into consideration. Since in the EEZ, in contrast to terrestrial areas, there is only one comprehensive spatial planning level, more detailed decisions on mitigation have to be taken in the overall spatial plans.

According to Principle 6 of Section 2 para. 2 FSPA, natural assets shall be used sparingly and carefully. To this end, the FSPA explicitly allows the placing of conditions and time limits on uses through stipulations made at the planning level to minimize environmental impacts. ${ }^{76}$ Particularly, it has to be ensured that the planning stipulations will not adversely affect the integrity of a Natura 2000 site. ${ }^{77}$ In the environmental report, the planned measures to avoid, mitigate or compensate for adverse effects on the environment must be described. ${ }^{78}$

In the spatial plans, there are source-related targets and principles as well as general principles for the mitigation of adverse impacts on the marine environment. The spatial plans stipulate, for example, in Section 3.5 on energy

74 Biodiversity Information Service System for Europe, 'Indicators for ecosystem services' $<$ http://biodiversity.europa.eu/maes/mapping-ecosystems/indicators-for-ecosystem -services-marine> accessed 30 September 2018.

European Commission, DG Environment, The Multifunctionality of Green Infrastructure (2012) Science for Environment Policy 18-19 <http://ec.europa.eu/environment/nature/ ecosystems/docs/Green_Infrastructure.pdf $>$.

76 Section 7 para. 1 FSPA.

77 Section 7 para. 6 FSPA in conjunction with Section 34 Nature Conservation Act.

78 Annex 1 no. 2 lit. $c$ to Section 8 para. 1 FSPA. 
production, that in planning and designing for the construction and operation of energy production facilities, negative impacts on the marine environment, in particular on its natural functions and on the marine ecosystem, shall be avoided. Best environmental practice according to the OSPAR Convention ${ }^{79}$ and state-of-the-art technology shall be taken into account.

In addition, environmental compatibility of maritime uses is verified at the following approval level for individual projects. The approval procedures for potentially harmful projects and activities in the marine zone are complex and wide-ranging. The applicant is generally required to carry out an environmental impact assessment (EIA), for which the approval authorities set the scope. The procedure is regulated by the Environmental Impact Assessment Act. ${ }^{80}$ If a plan or project, individually or in combination with others, is likely to have a significant effect on a Natura 2000 site, it is subject to an additional assessment of its implications for the site in view of the site's conservation objectives. ${ }^{81}$ Concrete measures to mitigate the impacts of uses on the marine environment will then be determined by the approval authority at project level taking into account specific conditions in the particular project area. Even in a priority area, the priority use can be made subject to conditions or obligations. ${ }^{82}$

In conclusion, the decision as to how a use is conducted in the EEZ should not be completely delegated to the approval level. However, while the process of marine spatial planning allows for space to be allocated, conflicts reduced and synergies maximized in order to avoid or mitigate the negative effects of uses on the environment, the quality of uses and the concrete impacts of individual projects cannot be fully controlled. ${ }^{83}$ For this reason, other procedures, such as EIA, must be employed alongside marine spatial planning to minimize the environmental impact of uses.

If significant adverse effects of uses are nevertheless unavoidable, they are to be offset via compensation measures or substitution measures or, where such offset is not possible, via monetary substitution, according to Section 13

79 HeLCOM Convention for the Baltic Sea.

8o Environmental Impact Assessment Act of 24 February 2010 (Federal Law Gazette, Part I, No 7/94), last amended by the Act of 15 September 2017 (Federal Law Gazette, Part. 1 No 62/3370).

81 Section 34 para. 1 Nature Conservation Act.

82 Dressler and others, Weiterentwicklung der Landschaftsrahmenplanung und ihre Integration in die Regionalplanung (Landwirtschaftsverlag 2000) 29 Angewandte Landschaftsökologie 154 .

83 Angela Schultz-Zehden, Kira Gee and Katarzyna Scibior, 'Handbook on Integrated Maritime Spatial Planning' (INTERREg III B CADSES PlanCoast Project, 2008) $22<w w w$ .plancoast.eu/files/handbook_web.pdf>. 
et seq. of the Nature Conservation Act. ${ }^{84}$ To ensure the actual protection of the marine environment, the Nature and Landscape Conservation Act of the federal state Mecklenburg-Western Pomerania, puts this obligation in more concrete terms by stating that impairments should be compensated for in the marine and not in the terrestrial area. ${ }^{85}$

The strict compensation obligation stipulated in the Nature Conservation Act cannot be circumvented by prioritizing other interests. However, it only becomes applicable at the project level, since the adoption of a plan in and of itself does not yet constitute an intervention in the marine environment. A plan constitutes, with regard to anthropogenic uses, only an 'offer' and, at the time of its adoption, it is not yet clear if and in which way specific projects will be realized. ${ }^{86}$ Rarely is the margin of discretion of the approval authority sufficiently 'condensed' by spatial planning stipulations to be able to predict the concrete extent of impacts that require compensation. Thus, specific compensatory measures for specific uses are imposed at the approval, not at the planning, level. ${ }^{87}$

At the superordinate planning level, the FSPA does not provide for a comparably strict compensation regime, but generally follows the concept of the Nature Conservation Act by including among the non-binding principles in Section 2 the principle that any impairment of the ecosystem shall be compensated for. ${ }^{88}$ The benchmark in this regard is the preservation of ecosystem functioning. ${ }^{89}$ Compensation can, however, take place on a larger scale. Thus,

84 For the construction and the operation of wind turbines in the German EEz, Section 56 para. 3 of the Nature Conservation Act provides for a wide exception from the strict compensation regime.

85 Cf. Section 3a para. 3 sentences 5 and 6 of the Nature and Landscape Conservation Act of the federal state Mecklenburg-Western Pomerania (LNatG M-V / GVOBl. M-V 2003/1).

86 Catrin Schmidt, 'Umweltprüfung und FFH-Verträglichkeitsprüfung von Raumordnungsplänen' in Dieter Eberle and Christian Jacoby (eds), Umweltprüfung für Regionalpläne (Akademie für Raumforschung und Landesplanung 2003) 56, 56-57.

87 Johann Köppel, Wolfgang Wende and Alfred Herberg, 'Naturschutzfachliche und naturschutzrechtliche Anforderungen im Gefolge der Ausdehnung des Raumordnungsregimes auf die deutsche Ausschließliche Wirtschaftszone' (Schriften des Bundesamtes für Naturschutz 2006) 82.

88 Willy Spannowsky, Peter Runkel and Konrad Goppel, ROG - Raumordnungsgesetz (Verlag C.H. Beck München, 2010) § 2 para 134.

89 Johann Köppel, Wolfgang Wende and Alfred Herberg, 'Naturschutzfachliche und naturschutzrechtliche Anforderungen im Gefolge der Ausdehnung des Raumordnungsregimes auf die deutsche Ausschließliche Wirtschaftszone' (Schriften des Bundesamtes für Naturschutz 2006) 68; Federal Agency for Nature Conservation, Naturschutzfachlicher Planungsbeitrag des Bundesamtes für Naturschutz zur Aufstellung von Zielen und Grundsätzen der Raumordnung für die deutsche Ausschließliche Wirtschaftszone der Nord- und 
full compensation does not have to be achieved in each small sub-area. Rather, the objective is to achieve a sustainable and overall balanced development of the sea. ${ }^{90}$ Accordingly, the consideration of compensation possibilities takes place within the weighing of interests stage of the planning process. ${ }^{91}$

In addition, in spatial plans, provision can already be made for compensatory measures that will presumably be required in the future pursuant to the stipulations of the Nature Conservation Act. ${ }^{92}$ Particularly if the spatial plan designates areas for potentially harmful projects and activities, corresponding areas for compensation should be provided for. Ideally, the limits of compensation possibilities set by a spatial plan also set a limit for impacts on the environment and thereby ensure sustainable development. ${ }^{93}$ For example, in the State Spatial Development Programme of Mecklenburg-Western Pomerania, the regional planning authority is assigned the task of considering the designation of such compensation areas. Compensatory measures shall then be carried out primarily in Natura 2000 sites and areas designated as part of a biotope network (Section 6.1.1, Principle 4). In the spatial plans for the EEZ, compensation areas have not yet been designated.

Due to the complexity of ecosystem functions, it is, in any event, difficult to achieve appropriate compensation in respect of marine areas. ${ }^{94}$ Firstly, compensation measures in the sea are more difficult to identify than those on land, where compensatory landscaping measures can be implemented. ${ }^{95}$ Possible

Ostsee (2006) 13 available online at <www.bfn.de/fileadmin/MDB/documents/themen/ landschaftsplanung/Planungsbeitrag_zur_Raumordnung_AWZ_20o6.pdf $>$.

90 Willy Spannowsky, Peter Runkel and Konrad Goppel, ROG - Raumordnungsgesetz (Verlag C.H. Beck München, 2010) § 1 para 101, 102.

91 Section 7 para. 2 FSPA.

92 The realization of compensation and substitution measures before interventions in nature occur is now possible in the EEz due to the insertion of Section 56a in the Nature Conservation Act in September 2017 (Federal Law Gazette, Part I, No 64/3434). After realization, the compensation value of the measures is credited to an eco-account and can be used for the compensation of an intervention at a later time. This possibility of a temporal decoupling of the intervention and the corresponding compensation increases flexibility in implementing compensation measures and could find reflection in future spatial planning stipulations.

93 Akademie für Raumforschung und Landesplanung, Nachhaltigkeitsprinzip in der Regionalplanung - Handreichung zur Operationalisierung (2000) Forschungs- und Sitzungsberichte vol 212, 211.

94 Thomas Robers, 'Das Gebot der nachhaltigen Entwicklung als Leitvorstellung des Raumordnungs- und Bauplanungsrechts' (2003) 209 Beiträge zur Raumplanung und zum Siedlungs- und Wohnungswesen 63.

95 Johann Köppel, Wolfgang Wende and Alfred Herberg, 'Naturschutzfachliche und naturschutzrechtliche Anforderungen im Gefolge der Ausdehnung des Raumordnungsregimes 
measures include restrictions on other, less important uses or the designation of priority areas for nature protection. Secondly, there has to be a functional relation between the compensation and the interference with an ecosystem. Only if compensation helps to preserve the respective ecosystem, compensation can be considered a suitable instrument to implement the ecosystem approach. ${ }^{96}$ Often, only parts of the complex ecosystem functions can be compensated for. ${ }^{97}$ Since compensation always implies that an ecosystem has been seriously damaged or even destroyed, the avoidance of negative impacts should be the primary objective of planning.

\subsection{Relational Understanding}

In order to implement the ecosystem approach, it is, according to the EBAGuideline, necessary to consider various effects on the ecosystem caused by human activities and interactions between human activities and the ecosystem, as well as among various human activities. This includes direct/indirect, cumulative, short/long-term, permanent/temporary and positive/negative effects, as well as interrelations including sea-land interaction.

When weighing up the different spatial demands in the planning process in accordance with Section 7 para. 2 of the FSPA, all relevant effects on the ecosystem are to be taken into account. The principles in Section 2 of the FSPA further emphasise the importance of the consideration of interactions in the environment ${ }^{98}$ and therefore also, for example, of cumulative effects. ${ }^{99}$ Additionally, the amended FSPA now explicitly requires the consideration of landsea interactions with regard to spatial planning measures in the territorial sea and the EEZ. ${ }^{100}$

Moreover, the interactions between the listed objects of protection, including species, plants and biological diversity, must be investigated in the environmental assessment on the consequences of the implementation of the plan

auf die deutsche Ausschließliche Wirtschaftszone' (Schriften des Bundesamtes für Naturschutz 2006) 82.

96 Detlef Czybulka, 'Der Ökosystemansatz als Managementprinzip des Naturschutzes', in Lothar Knopp and Heinrich Amadeus Wolff (eds), Umwelt - Hochschule - Staat: Festschrift für Franz-Joseph Peine zum 7o. Geburtstag (Duncker \& Humblot 2016) 21, 35 .

97 Thomas Robers, 'Das Gebot der nachhaltigen Entwicklung als Leitvorstellung des Raumordnungs- und Bauplanungsrechts' (2003) 209 Beiträge zur Raumplanung und zum Siedlungs- und Wohnungswesen 63.

$98 \quad$ Section 2 para. 2 no. 6 FSPA.

99 Edmund Brandt and Karsten Runge, Kumulative und grenzüberschreitende Umweltwirkungen im Zusammenhang mit Offshore-Windparks (Nomos 2002) 44.

100 Section 13 para. 6 and Section 17 para. 1 FSPA (in implementation of Art. 1 para. 2, Art. 4 para. 2 und 5, Art. 6 para. 2 lit. a und Art. 7 para. 1 MSP-Directive). 
and described and evaluated in the environmental reports. ${ }^{101}$ In the environmental reports for the current spatial plans, various types of interactions have thus been described including, inter alia, interactions amongst subjects of protection and direct and indirect effects, as well as temporal and permanent, local and large-scale, marginal and severe, positive and negative and cumulative effects. ${ }^{102}$

The consideration of all direct and indirect impacts of anthropogenic activities on the structures and the functioning of ecosystems within the planning process as intended by the EBA-Guideline is a very desirable aim. However, marine ecosystems have many interacting components that are not yet fully understood ${ }^{103}$ and uncertainty seems to be virtually inherent in such a complex concept as the ecosystem approach. This uncertainty is aggravated by the fact that, because of the general nature of the plans, the prediction of their effects is rather difficult at the planning level. ${ }^{104}$ Thus, while scientific research should strive to reduce uncertainty by investigating knowledge gaps on relational understanding, this should not prevent planning. To allow otherwise means that knowledge gaps and the corresponding requirement of further research can lead to significant delays in the adoption of spatial plans. The implementation of the ecosystem approach in that case runs the risk of becoming a hindrance to a rapid implementation of protective spatial measures. This possibility is referred to as the phenomenon of 'analysis paralysis'.105

Where current best available information indicates a serious risk to the marine environment, the better option is to take proportionate protective spatial planning measures in line with the precautionary principle rather than to wait until additional knowledge gain facilitates the development of more ecosystem-oriented measures. ${ }^{106}$ In the EBA-Guideline, the requirements for a 'relational understanding' seem, therefore, to be 'softened' by the reference

\footnotetext{
101 Section 8 para. 1 FSPA.

102 Federal Maritime and Hydrographic Agency, Non-technical summary of the Environmental Report for the North Sea, for example Sections 9.1.12, 9.3.3.1, 9.3.4.1, 9.3.7.1, 9.4.5.

103 Larry Crowder and Elliott Norse, 'Essential ecological insights for marine ecosystembased management and marine spatial planning' (2008) 32 Marine Policy 772, 776 .

104 Thomas Bunge, 'Möglichkeiten und Grenzen der „Abschichtung" bei der strategischen Umweltprüfung' in Dieter Eberle and Christian Jacoby (eds), Umweltprüfung für Regionalpläne (Akademie für Raumforschung und Landesplanung 2003) 20, 24.

105 Oxford Living Dictionaries, 'analysis paralysis' <https://en.oxforddictionaries.com/ definition/analysis_paralysis $>$ accessed 30 September 2018.

106 Sachverständigenrat für Umweltfragen, 'Meeresumweltschutz für Nord- und Ostsee' (Sondergutachten 2004) para $497<$ www.umweltrat.de/SharedDocs/Downloads/DE/ 02_Sondergutachten/2004_SG_Meeresumweltschutz_fuer_Nord_und_Ostsee.pdf? blob=publicationFile $>$.
} 
to the latest state of knowledge and to precaution as further key elements of the ecosystem approach. For the same reason, the necessary scope and level of detail of the assessment of the environmental impacts of a plan depends, pursuant to the FSPA, on what can be reasonably expected with regard to the current state of knowledge, generally accepted testing methods and the content and level of detail of the spatial plan. ${ }^{107}$

Remaining information gaps have to be revealed in the environmental reports. ${ }^{108}$ For example, the migratory patterns of bats and the possible negative impacts of maritime uses on their population development have been described as largely unknown. ${ }^{109}$ In such cases research is encouraged to be integrated into projects and the impacts of the project on the marine environment are to be subsequently monitored at project level. ${ }^{110}$ The results can then be fed into future approval and spatial planning processes as they progress. Since this approach harbours the risk that only project-specific impacts are considered and not all relevant ecosystem interrelations, ${ }^{111}$ overall impacts of the implementation of the spatial plan are also to be monitored. Applying such an iterative process and providing for adaptation possibilities can help to reconcile the requirements of a comprehensive relational understanding with the timely implementation of ecosystem-based spatial planning.

\subsection{Participation and Communication}

All relevant authorities and stakeholders as well as a wider public shall be involved in the planning process at an early stage according to the EBAGuideline. The results shall be communicated. In Germany, the public as well as potentially affected public authorities are to be notified of the preparation of a spatial plan and they have to be given the opportunity to comment on the draft plan. ${ }^{112}$ The result of the examination of the comments has to be made available. ${ }^{113}$ Since, pursuant to the MSP-Directive, member states shall facilitate public participation at an early stage in the development of maritime spatial plans, ${ }^{114}$ it is questionable whether it is necessary to ensure even

\footnotetext{
107 Section 8 para. 1 FSPA.

108 Annex 1 no. 3 lit. a to Section 8 para. 1 FSPA.

109 Federal Maritime and Hydrographic Agency, Non-technical summary of the Environmental Report for the North Sea, Section 9.3.9.2.

110 Ibid. Section 9.8.

111 Akademie für Raumforschung und Landesplanung, Maritime Raumordnung. Interessenlage, Rechtslage, Praxis, Fortentwicklung (2013) 1 Forschungsberichte der ARL 17.

112 Section 9 FSPA.

113 Section 10 para. 3 FSPA.

114 Directive 2014/89/EU, Art. 9 para. 1.
} 
greater upstream participation in the planning process, i.e. public participation already from the conception stage.

The planning process for the German EEz started in 2005 with the sending of a questionnaire to relevant agencies and NGOs asking for information on activities, licenses and interests in the EEZ. A 'scoping meeting' subsequently took place to discuss the scope of the necessary Strategic Environmental Impact Assessment. The вмVBS and the Federal Maritime and Hydrographic Agency (BSH) then drafted the marine spatial plans which, in conjunction with the environmental report, were published in 2008. Broad public participation was ensured through consultations with stakeholders from different sectors, including the marine environment and nature conservation, fisheries, energy, sand and gravel, shipping, military, tourism, leisure boating and research. A public hearing on the draft plan, attended by approximately 80 stakeholders, was held in Rostock at the end of 2008.115

Integrated Coastal Zone Management (IZCM), as an informal and flexible instrument, is recommended by the EBA-Guideline to support the process of participation and communication. It can be used to complement the formal participation process required by the FSPA. In Germany, following the European Parliament and Council Recommendation concerning the implementation of Integrated Coastal Zone Management in Europe of 30 May 2002 $(2002 / 413 / E C),{ }^{116}$ the German Federal Ministry for the Environment, Nature Conservation and Nuclear Safety, published an ICZM strategy in March 2006. According to the strategy, ICZM is planned as 'an informal approach to supporting sustainable development of coastal zones through good integration, coordination, communication and participation.'117

Even though the participation of the public and of potentially affected public authorities is imperative to enable consideration of all relevant interests in the planning process, such participation does not always entail better protection of the marine environment. For example, the public desire for an unimpaired view over the ocean might lead to the placement of wind energy installations further offshore, even in cases in which this is not the most

115 HELCOM / VASAB, Country Fiche - Germany (updated November 2016) 5, 8, $9<\mathrm{www}$ .helcom.fi/Documents/Action\%2oareas/Maritime\%2ospatial\%2oplanning/Country\%20 fiche_DE_Nov2016.pdf >.

116 Recommendation of the European Parliament and of the Council concerning the implementation of Integrated Coastal Zone Management in Europe [2002] OJ L 148/24.

117 Federal Ministry for the Environment, Natures Conservation and Nuclear Safety, Integrated Coastal Zone Management in Germany - Assessment and steps towards a national ICZM strategy (March 2006) 3 <www.ikzm-strategie.de/dokumente/ikzm_englisch_final $. \mathrm{pdf}>$. 
environmentally-friendly alternative. ${ }^{118}$ Moreover, broad participation rights entail the risk of 'participatory paralysis'. For example, the amendment of the FSPA requires the next generation of plans to be established in agreement with all ministries concerned. ${ }^{119}$ It remains to be seen whether this provision ensures improved ecosystem protection by requiring the agreement of the Ministry for the Environment or hinders the needed change towards ecosystem protection by requiring the agreement of all ministries concerned. ${ }^{120}$

With regard to international participation, other states must be involved in the planning process pursuant to the FSPA if there is a risk of significant impacts of the planning stipulations on their territory. ${ }^{121}$ If there is reason to fear significant impacts on the environment of a neighbouring state, its participation is regulated by the Environmental Impact Assessment Act. ${ }^{122}$ In addition, Section 17 para. 1 of the $\mathrm{FSPA}^{123}$ requires the BMVI to consult with the neighbouring states on the plans. Before the current plans were adopted, neighbouring states were thus involved in the planning process by notifying them about the intention of Germany to set up a marine spatial plan. Several face-to-face meetings with representatives of those countries took place, as well as consultations during the environmental assessment of the draft plan, with a view to taking into consideration potential negative impacts of the plan on the marine environment in these neighbouring countries. ${ }^{124}$ The newly adopted HELCOM-VASAB Guidelines on transboundary consultations, public participation and co-operation ${ }^{125}$ could, in the future, provide a basis for

118 Helle Tegner Anker, presentation on 'Ecosystem perspectives in planning for offshore wind energy projects - does participation matter?', Conference The Ecosystem Approach in Ocean Planning and Governance (University of Gothenburg, 2016).

119 Section 17 para. 1 FSPA.

120 The plan to require the Ministry for the Environment to obtain the agreement of other ministries for the declaration of marine areas as protected parts of nature and landscape in Section 57 para. 2 of the Nature Conservation Act has been abandoned due to the risk that they may block effective measures for the protection of the marine environment / cf. Deutscher Bundestag, Recommended Resolution and Report of the Committee for the Environment, Nature Conservation, Building and Nuclear Safety (document: Drucksache $18 / 12845,2017) 22$. Of course, the focus of spatial planning is not only on environmental protection, which might justify a greater involvement of the various ministries.

121 Section 9 para. 4 FSPA.

122 Sections 6o and 61 Environmental Impact Assessment Act.

123 Section 17 para. 3 FSPA / old version.

124 HeLCOM / VASAB, Country Fiche - Germany (updated November 2016) $9<$ www.helcom.fi/ Documents/Action\%2oareas/Maritime\%2ospatial\%2oplanning/Country\%2ofiche_DE_ Nov2016.pdf $>$.

125 HELCOM / VASAB, Guidelines on transboundary consultations, public participation and cooperation, adopted by the 72nd meeting of VASAB CSPD/BSR on 8 June 2016 and approved by HELCOM HOD 50-2016 on 15-16 June 2016. 
a comprehensive, constant and long-term cooperation in the development of spatial plans.

\subsection{Subsidiarity and Coherence}

Pursuant to the EBA-Guideline, maritime spatial planning with an ecosystembased approach as an overarching principle shall be carried out at the most appropriate level and shall seek coherence between the different levels. If marine spatial planning is designed as a multi-scalar process ranging from regional to local planning, the most appropriate level can be chosen depending on the issue to be tackled. ${ }^{126}$ Regional planning in the German mainland and the 12 nautical mile territorial sea is the responsibility of the coastal federal states (Länder) and the regional authorities. The legal bases for planning are the FSPA and the respective spatial planning laws of the individual federal states. The German federal structure has thus resulted in a decentralized planning system with legally, organizationally, and substantively differentiated planning levels. In contrast, responsibility for overall spatial planning in the German EEz has been exclusively assigned to the federal government by Section 17 para. 1 of the FSPA. ${ }^{127}$ This single-level planning does not prevent the planning authority from choosing different levels of planning detail according to the ecosystems needs in the planning area.

The delimitation of planning areas in Germany reflects the German administrative structures rather than the boundaries of marine ecosystems, which could mitigate against the delivery of an ecosystem approach. Ensuring the coherence of spatial plans across all sizes of marine ecosystems is therefore particularly important and challenging. In the German mainland, the different planning levels are interlinked in a coherent planning system by the mutual feedback principle as well as by comprehensive requirements of notification, participation, coordination and compliance. ${ }^{128}$ According to the mutual feedback principle, the various planning levels have to take the requirements and conditions of the other levels into account. ${ }^{129}$ For the EEZ, the provisions of the FSPA also require an internal coherence of the spatial plans. The spatial plans for the EEZ should contain provisions concerning the safety and efficiency of maritime traffic, economic and scientific uses, and the protection

126 University of Thessaly, Paving the road to Marine Spatial Planning in the Mediterranean, Final Report MSP-Med - Greece (December 2015) $114<$ http://www.pap-thecoastcentre .org/pdfs/MSP\%2oMed\%2oFinal\%2oReport.pdf>.

127 Section 17 para. 3 FSPA / old version.

128 Gerd Turowski, 'Raumplanung' in Akademie für Raumforschung und Landesplanung (ed), Handwörterbuch der Raumordnung (2005) 893, 895.

129 Section 1 para. 3 FSPA. 
and improvement of the marine environment. ${ }^{130}$ Despite this enumeration of sectors, planning in the EEZ shall be based, within the limits set by the United Nations Convention on the Law of the Sea (LOSC), ${ }^{131}$ on a comprehensive and coherent concept. ${ }^{132}$

Since conflicts between uses and the protection of ecosystems do not stop at the border between the territorial sea and the EEz, coherence between the spatial plans for the EEZ and the plans of the adjacent federal states is crucial to ensure ecosystem protection. The problem of the distribution of competences between the territorial sea and the EEZ becomes clear with regard to the implementation of the ecosystem approach, for example, when the protection of a migration corridor or the establishment of a network of protected areas requires coherent regulations across administrative boundaries. ${ }^{133}$ Section 17 para. 3 of the former version of the FSPA therefore stipulated that the BMVI must establish the plans for the EEZ in consultation with the neighbouring federal states. Before the spatial plans were adopted, coordination processes were thus carried out with all federal states which were active in the coastal waters with regard to spatial planning. ${ }^{134}$ Now, all three federal states located on the German coast (Mecklenburg-Western Pomerania, Lower Saxony and Schleswig-Holstein) have adopted relevant programmes and plans for the territorial sea. The mere requirement of consultation, however, was not able to ensure full coherence between the spatial plans for the territorial sea and for the EEZ. Through the amendment, the BMVI is now required to cooperate with neighbouring federal states with the aim of ensuring that marine spatial plans are coherent and coordinated. ${ }^{135}$

Potentially, the informal instrument of ICZM could complement spatial planning and further mitigate the consequences of the distribution of competences by facilitating communication and cooperation. The German ICZM strategy follows a spatially comprehensive approach and takes the interactions

\footnotetext{
130 Section 17 para. 1 FSPA.

131 United Nations Convention on the Law of the Sea, 1833 UNTS 3; 21 ILM 1261 (1982).

132 Deutscher Bundestag, Draft Act amending the Federal Spatial Planning Act (document: Drucksache 16/10292, 2008) 28.

133 For example, the Federal Agency for Nature Conservation recommended the establishment of a migration corridor to Mecklenburg-Western Pomerania that has not been included in the State Spatial Development Programme finally adopted (cf. position statement of 2015 available on the internet at http://awd.mv-regierung.de/lep_2016_o1/anz kuerzel.php).

134 Federal Maritime and Hydrographic Agency, Non-technical summary of the Environmental Report for the North Sea / the Baltic Sea, Section 9.1.2 respectively.

135 Section 17 para. 1 FSPA.
} 
between the EEZ, coastal waters and transitional waters ${ }^{136}$ and areas adjoining estuaries and influenced by the tides, as well as rural districts on the coast, into account. ICZM is actually the only level in Germany at which this functionally cohesive area, the coastal and marine zone, is considered in its entirety. ${ }^{137}$ The integrated coastal zone management concept has to be taken into consideration during the weighting of all relevant interests in the planning process, which is required by Section 7 para. 2 of the FSPA. ${ }^{138}$ In any event, the interaction between informal and formal instruments still needs to be developed in Germany to exploit all possible synergies. ${ }^{139}$

As to the minimum necessary extent of a coherent spatial planning concept, the delimitation of Large Marine Ecosystems, ${ }^{140}$ whose boundaries are based on the four linked ecological criteria bathymetry, hydrography, productivity, and trophic relationships and of Marine Ecoregions, ${ }^{141}$ whose boundaries reflect large-scale ecological patterns can offer some guidance. Both concepts propose rather large areas, such as the North Sea and the Baltic Sea, as the spatial basis for nature conservation. In the same spirit, the MSP-Directive now requires cooperation with the aim of ensuring that maritime spatial plans are coherent and coordinated across the respective marine region. As marine regions are enumerated inter alia the Baltic Sea and the North-east Atlantic Ocean, thus also large areas. ${ }^{142}$ The FSPA does not refer to marine regions, but requires the cooperation with neighbouring countries. ${ }^{143}$ Importantly, this cooperation is not only to concern certain formulations for a concrete plan,

${ }_{13} 6$ Cf. Definition in Art. 2 of the Directive 200o/6o/EC of the European Parliament and of the Council establishing a framework for Community action in the field of water policy (Water Framework Directive) [2000] OJ L 327/1.

137 Federal Ministry for the Environment, Natures Conservation and Nuclear Safety, Integrated Coastal Zone Management in Germany - Assessment and steps towards a national ICZM strategy (March 2006) 3, 7 <www.ikzm-strategie.de/dokumente/ikzm_englisch_ final.pdf $>$.

138 Deutscher Bundestag, Draft Act amending the Federal Spatial Planning Act (document: Drucksache 18/10883, 2017) 41, 42.

139 Federal Environment Agency, Report on the Implementation of Integrated Coastal Zone Management in Germany (National ICZM Report, 2011) 15-16 <www.umweltbundesamt .de/sites/default/files/medien/371/publikationen/national_report_iczm_in_germany .pdf >.

140 US National Oceanic and Atmospheric Administration (NOAA), 'Ecosystem Science' $<$ www.st.nmfs.noaa.gov/ecosystems/lme/index > accessed 28 September 2018.

141 Cf. Mark D. Spalding and others, 'Marine Ecoregions of the World: A Bioregionalization of Coastal and Shelf Areas' (2007) 57(7) BioScience 573, 573-582.

142 Directive 2014/89/EU, Art. 11 para. 1 and Art. 3 para. 3 in conjunction with Directive 2008/56/EC, Art. 4 para. 1.

143 Section 17 para. 1. 
but shall rather be broadly understood. ${ }^{144}$ Since the outcome - in other words the necessary level of coherence and coordination - is neither specified in the MSP-Directive nor in the amendments to the FSPA, a level of coherence of spatial plans adequate for ecosystem protection across a particular marine region seems, however, not yet guaranteed.

\subsection{Adaptation}

The sustainable use of the ecosystem should, according to the EBA-Guideline, apply an iterative process including monitoring, reviewing and evaluation of both the process and the outcome. The German spatial plans were comprehensively assessed by the planning authority before their adoption in 2009. The assessment formed the foundation for the environmental report, according to which, 'positive effects on the marine environment due to the designations of the Maritime Spatial Plan regarding the marine environment are to be anticipated for the totality of the subjects of protection. ${ }^{145}$

In 2012, an evaluation report was produced by the BSH and the BMVBS, which assessed whether and if so how the implementation of the plans had been successful in reaching its targets. The evaluation focused, however, mainly on the development of offshore wind energy and the target set by the Federal government for offshore wind energy production. The existence of ecological steering effects of the spatial plans has been derived from the fact that offshore windfarm applications have been received only for the priority areas for offshore wind energy and for areas with no general limitation on offshore wind farm development. ${ }^{146}$

Until recently, no time limit was set for a comprehensive review of the spatial plans. The provisions of the plans were, as a consequence, 'perpetuating' the results of the balancing process and the corresponding state of knowledge. ${ }^{147}$ Since the MSP-Directive requires maritime spatial plans to be reviewed by member states at least every ten years, ${ }^{148}$ the FSPA has now been amended accordingly. ${ }^{149}$ With regard to ecosystem protection, it seems unfortunate that

\footnotetext{
144 Deutscher Bundestag, Draft Act amending the Federal Spatial Planning Act (document: Drucksache 18/10883, 2017) 47 .

145 Federal Maritime and Hydrographic Agency, Non-technical summary of the Environmental Report for the North Sea 67.

146 HELCOM / VASAB, Country Fiche - Germany (updated November 2016) $9<$ www.helcom .fi/Documents/Action\%2oareas/Maritime\%2ospatial\%2oplanning/Country\%2ofiche DE_Nov2016.pdf>.

147 Guy Beaucamp, Das Konzept der zukunftsfähigen Entwicklung im Recht (Mohr Siebeck 2002) 418 .

148 Directive 2014/89/EU, Art. 6 para. 3.

149 Section 7 para. 8 FSPA.
} 
the opportunity was not taken to harmonize the review period under the FSPA with the review period of six years for marine strategies provided for in the Marine Strategy Framework Directive (2008/56/EC / MSFD $)^{150}$ and to thereby ensure a timely adaptation of spatial plans to the knowledge gain expected within the MSFD system. Moreover, the planning process itself is not under regular evaluation in Germany.

According to Section 8 para. 4 of the FSPA, significant impacts of the implementation of the spatial plans are to be continuously monitored in order to identify unexpected impacts on the environment at an early stage and to be able to take appropriate corrective measures. The intended plan-related monitoring measures include the consolidation and analysis of project-related impact monitoring efforts and the analysis of national and international monitoring programmes. ${ }^{151}$ However, no monitoring has to take place to examine whether the plans continuously reflect the latest state of knowledge and whether the highest practicable level of protection for marine ecosystems is achieved.

\section{Ecosystem Protection: Current State in the German EEZ and Ideas} for Improvement

\subsection{Ecosystem Definition}

To avoid marine spatial planning being 'decoupled from the ecosystem despite being framed as a tool for ecosystem-based management' ${ }^{152}$ the characteristics of ecosystems have to be taken into account and ecosystem protection prioritised as the ultimate objective of the ecosystem approach. According to Art. 2 of the Convention on Biological Diversity, the term 'ecosystem' means a 'dynamic complex of plant, animal and micro-organism communities and their non-living environment interacting as a functional unit'. This definition does not specify any particular spatial unit or scale. Depending on the problem being addressed, an ecosystem could, for example, be a grain of soil, a pond,

150 Art. 17 para. 2 Directive 2008/56/EC of the European Parliament and of the Council establishing a framework for community action in the field of marine environmental policy (Marine Strategy Framework Directive) [2008] OJ L 164/19.

151 Federal Maritime and Hydrographic Agency, Non-technical summary of the Environmental Report for the North Sea 81 .

$15^{2}$ Andrew Merrie and Per Olsson, 'An innovation and agency perspective on the emergence and spread of Marine Spatial Planning' (2014) 44 Marine Policy 366, 366. 
a forest, a biome or the entire biosphere. ${ }^{153}$ Several key characteristics of an ecosystem have been identified. ${ }^{154}$ For the purpose of spatial planning, it is interesting that an ecosystem is considered to exist in a space with boundaries, even though such geographical boundaries can never encompass all relevant ecosystem processes. What presents a major challenge for considering ecosystems in marine spatial planning is, however, that they are dynamic; thus their structure and function change with time.

Ecosystem management that tries to isolate significant system components has been recognized as being incompatible with the fundamental nature of marine ecosystems. A wider systems context thus has to be taken into consideration when developing spatial planning measures aimed at ecosystem protection. ${ }^{155}$ The ecosystem must be managed 'as a whole rather than as the sum of its parts' 156 This requires the recognition of living species and their physical environments as interconnected and a focus on the interaction between different sub-systems and their responses to stresses resulting from human activity. ${ }^{157}$ The question arises as to whether the German spatial planning tools provide for the possibility to fully account for the characteristics of ecosystems and to what extent they have been used so far to ensure ecosystem protection.

\subsection{Respect of the Carrying Capacity of Ecosystems}

The carrying capacity of marine ecosystems may be understood as the development threshold that cannot be exceeded without irremediably going against environmental objectives. ${ }^{158}$ Approaching the limits of the carrying capacity of marine ecosystems may result in the deterioration of ecosystem services, the loss of biodiversity and habitat heterogeneity and, finally, the

153 Convention on Biological Diversity, CoP 5 Decision v/6, 'Ecosystem Approach' <www .cbd.int/decision/cop/?id=7148> accessed 30 September 2018.

154 Serge Michel Garcia and others, 'The ecosystem approach to fisheries' FAo Fisheries Technical Paper no 443 (2003) 7-8.

155 Parliamentary Commissioner for the Environment of New Zealand, Setting Course for a Sustainable Future: The Management of New Zealand's Marine Environment (1999) 56-57 $<$ www.pce.parliament.nz/media/pdfs/Sustainable_Future_report.pdf>.

156 European Environment Agency, State of Europe's seas EEA (Report No 2/2015) 192.

157 Jutta Brunnée and Stephen J Toope, 'Environmental Security and Freshwater Resources: A Case for International Ecosystem Law' in Handl (ed), 5 Yearbook of International Environmental Law (Oxford University Press 1994) 41, 55 .

${ }_{15} 8$ Cf. definition for the carrying capacity of the coastal zone in: The Black Sea Countries Contracting Parties to the Bucharest Convention, Guideline on Integrated Coastal Zone Management in the Black Sea, Annex Explanatory and Reference Notes to Sections of Guideline. 
breakdown of ecosystem resilience. ${ }^{159}$ According to recital 14 of the MSPDirective, the ecosystem-based approach thus aims at ensuring that the capacity of marine ecosystems to respond to human-induced changes is not compromised. It is questionable whether the stipulations of the FSPA ensure the preservation of the capacity of marine ecosystems to cope with environmental stress. According to the general guideline for spatial development set out in Section 1 para. 2 of the FSPA, the social and economic demands have to be reconciled with the relevant area's ecological functions. Spatial development is thus not purely dominated by ecological considerations. ${ }^{160}$ Preserving ecological functions, however, constitutes, according to the wording of Section 1, the benchmark for the consideration of social and economic interests.

To implement Art. 5 para. 1 of the MSP-Directive, Section 2 para. 2 no. 6 of the FSPA now promotes the support of sustainable development in the marine area, applying an ecosystem-based approach. The EBA-Guideline also refers to the sustainable use of ecosystems. Sustainability is often considered to require the achievement, in equal value, of its three pillars: economic, environmental and social issues. ${ }^{161}$ Linking the ecosystem approach with 'sustainable use' therefore seems to risk diluting its ecological direction and thrust and thus undermining the protection of ecosystems. ${ }^{162}$ Since functional ecosystems are an essential precondition for social and economic development, the balance between economic, social and environmental interests, however, can be found only within the framework of environmental compatibility. ${ }^{163}$ The concept of sustainable development thus implies limits imposed by the ability of the biosphere to absorb the effects of human activities. ${ }^{164}$

According to the FSPA (Section 7 para. 2), public and private interests are to be identified and weighted against each other in view of the preparation of the spatial plans. When balancing the different interests, the results of the

159 Chang Hui, 'Carrying Capacity of the Environment' in James D Wright (ed), International Encyclopedia of the Social \& Behavioral Sciences (Elsevier 2015, 2nd edn) 155, 157-158.

160 Willy Spannowsky, Peter Runkel and Konrad Goppel, ROG - Raumordnungsgesetz (Verlag C.H. Beck München, 2010) § 1 para 94.

161 United Nations, Johannesburg Declaration on Sustainable Development, World Summit on Sustainable Development, A/CONF.199/20, Chapter 1, Resolution 1, Johannesburg (September 2002) point 5 .

162 Sachverständigenrat für Umweltfragen, 'Meeresumweltschutz für Nord- und Ostsee' (Sondergutachten 2004) para 498.

163 Akademie für Raumforschung und Landesplanung, Nachhaltigkeitsprinzip in der Regionalplanung - Handreichung zur Operationalisierung (2000) Forschungs- und Sitzungsberichte vol 212, 13 .

164 World Commission on Environment and Development, Our Common Future (Brundtland Report 1987) para 27. 
environmental assessment have to be taken into account. At least if the sea could be affected by planning decisions to such an extent that its ecosystems might not recover, it is hard to imagine that sufficient weight has been given to the protection of the environment in the balancing process. ${ }^{165}$ Allowing anthropogenic activities to exceed the carrying capacity of the marine environment would most likely constitute a manifest error of assessment and would therefore also exceed the discretionary power attributed to the planning authority by the FSPA. Beyond that limit, however, no principal priority has to be given to ecological considerations.

Consequently, the aforementioned stipulations of the FSPA theoretically seem to ensure at least respect for the carrying capacity of marine ecosystems within the planning process. To ensure respect for the carrying capacity of ecosystems in practice, ideally, specific limits are identified for pressures on marine ecosystems and planning stipulations designed accordingly. Yet, significant questions arise as to whether a specific threshold for an entire ecosystem can really be set due to the complexity and dynamic quality of ecosystems. ${ }^{166}$ In this regard, recital 13 of Commission Decision (EU) 2017/848 is interesting, according to which the setting of threshold values should accommodate the dynamic nature of marine ecosystems and their elements. Furthermore, threshold values should reflect the fact that marine ecosystems may recover, if deteriorated, to a state that reflects prevailing physiographic, geographic, climatic and biological conditions, rather than return to a specific state of the past. ${ }^{167}$ In the face of uncertainty, the application of the precautionary principle through the incorporation of appropriate safety margins can help to avoid irreversible harm to the marine environment.

\subsection{Ecosystem Protection in the FSPA and the Marine Spatial Plans}

One of the principles for nature conservation listed in Section 2 para. 2 no. 6 of the FSPA that can be equally applied in the terrestrial and the marine area is that space shall be developed, protected and, where necessary, possible and

\footnotetext{
165 Mathias Schubert, 'Meeresraumordnung und Europarecht: Die Richtlinie 2014/89/EU zur Schaffung eines Rahmens für die maritime Raumplanung', in Timo Hebeler (ed), Jahrbuch des Umwelt- und Technikrechts (2015) 199, 210-211.

166 European Commission, DG Environment, The Multifunctionality of Green Infrastructure (2012) Science for Environment Policy $20<$ http://ec.europa.eu/environment/nature/ ecosystems/docs/Green_Infrastructure.pdf $>$.

167 Commission Decision (EU) 2017/848 laying down criteria and methodological standards on good environmental status of marine waters and specifications and standardised methods for monitoring and assessment, and repealing Decision 2010/477/EU [2017] OJ L 125 .
} 
appropriate, restored to maintain the functioning of soils, the water balance, the fauna and flora as well as the climate, including respective interactions. To fully implement Art. 5 para. 1 of the MSP-Directive, support for the sustainable development of the marine area using the ecosystem approach is now required. ${ }^{168}$ The FSPA, however, contains no detailed specification taking account of the special characteristics of the marina area and its exposure to special threats.

The focus of marine environmental protection in the spatial plans for the EEZ is, according to Guideline 2.5, on marine fauna and flora including their biotopes and habitats and on bird migration routes. Sea water quality, hydrography and sediment conditions are also considered part of the marine environment. Principles specifically for the protection of the marine environment can be found in Section 3.7 on the marine environment. According to those principles, the EEZ shall be permanently safeguarded and developed further as an ecosystem with its typical features, interrelationships and interactions in order to preserve its biological diversity. In accordance with the guiding concept of sustainability, the natural resources shall be used economically and with care. Negative impacts on the ecosystem shall be avoided and minimized in accordance with the precautionary principle and the ecosystem approach. In addition, in permanently unused areas, the functions of the ecosystem are required to be restored to their original condition or preserved in a condition of ecological balance (3.7.1 Principles / Marine ecosystem).

In the section that specifically deals with the protection of the marine environment, only principles have been determined, not binding targets. The predominant approach of the German marine spatial plans to marine nature protection is a source-related approach, which means that principles and targets are set for certain uses in order to mitigate their impacts on the marine environment. Since it cannot be excluded that new maritime uses may emerge or that the impacts of maritime uses may be aggravated in an unexpected way, the rather general and non-binding principles for the protection of the marine environment might not ensure a complete and comprehensive protection of ecosystems.

\subsection{Potential of German Spatial Planning Tools for the Advancement of Ecosystem Protection}

To apply the ecosystem approach, planning authorities can ideally choose from a broad suite of tools and apply and adapt them according to the circumstances

168 Section 2 para. 2 no. 6 FSPA. 
in the area under their responsibility. ${ }^{169}$ The FSPA permits the establishment of different zones with different levels of protection. For example, core areas can be designated as priority areas and buffer zones as reserve areas. In that way, it is possible to ensure that activities occurring near a priority area protecting a particular ecosystem do not compromise its function. The designation of suitability areas furthermore allows the concentration of environmentally harmful uses in those areas. The Zoning Plan that covers the entire Great Barrier Reef Marine Park can serve as an example of a holistic and ecosystem-wide zoning approach. The plan defines what activities can occur in which locations both to protect the marine environment and to separate potentially conflicting activities. The level of protection increases from the General Use Zones up to the most restrictive, the Preservation Zone. ${ }^{170}$ Although the entire system is a designated Marine Protected Area, the management approach resembles that of spatial planning. In Germany, it would be possible to establish a similar multi-layered protection system by using the possibilities offered by the FSPA.

Moreover, some ecosystem components only require protection in one of the three dimensions of the sea (water surface, water column, and sea bed). For example, benthic communities only need protection from impacts on the sea bed, such as those from bottom-trawl fisheries. A 'layering' of areas with different levels of protection is possible to adapt the density and strictness of planning determinations to the specific need for protection in each layer. ${ }^{171} \mathrm{In}$ this context, the spatial plans explicitly recognize in their Guideline 2.4 that the sea surface, water column, seabed, subsoil and the airspace above may require different provisions regarding their protection and use. The explanatory statement for the draft amendment of the FSPA also clarifies that the uses and functions are to be coordinated by taking their extension to the three-dimensional space into account. ${ }^{172}$ In this regard, spatial planning could again learn from the experiences of regulation of uses in Marine Protected Areas. In Canada, for example, the Hecate Strait and Queen Charlotte Sound Glass Sponge Reefs Marine Protected Area was designated in February 2017. Each

169 Cf. Scottish Natural Heritage, 'An ecosystem approach to marine planning - a summary of selected tools, examples \& guidance' (2016) <www.nature.scot/sites/default/files/2017 -06/2016\%2005\%2018\%20-\%2oEcosystem\%2oapproach\%2oin\%2omarine\%20 planning\%20-\%20FINAL\%2oVersion\%201.pdf> 2 .

170 Australian Government, Great Barrier Reef Marine Park Authority, 'About Zoning' <www.gbrmpa.gov.au/zoning-permits-and-plans/zoning/about-zoning> accessed 30 September 2018.

171 Akademie für Raumforschung und Landesplanung, Maritime Raumordnung. Interessenlage, Rechtslage, Praxis, Fortentwicklung (2013) 1 Forschungsberichte der ARL 10.

172 Deutscher Bundestag, Draft Act amending the Federal Spatial Planning Act (document: Drucksache 18/10883, 2017) 37. 
glass sponge reef has a Core Protection Zone, a Vertical Adaptive Management Zone, and an Adaptive Management Zone. The Core Protection Zones consist of the seabed, the subsoil to a depth of $20 \mathrm{~m}$ and the water column above the seabed to a depth of about 10om below the sea surface. ${ }^{173}$

Even dynamic ecosystem components can be protected by the German spatial instruments. Examples of dynamic ocean features include eddies or fronts or the seasonal migration of species. ${ }^{174}$ However, to achieve a binding effect of respective spatial planning measures, the areas to be protected must be clearly identifiable. For example, in Australia, meso-scale eddies have been identified as key ecological features of the South-west Marine Region in the marine environment report card supporting the marine bioregional plan for that region. These eddies are persistent and form regularly in predictable locations. ${ }^{175}$

As noted in Section 4 lit. c above, temporal aspects can also be taken into consideration as a 'fourth dimension' of planning within the German system, taking account of the fact that the need for protection of ecosystem components can vary over time. The new Section 7 para. 1, which permits stipulations that allow uses only for a certain period of time or only under certain circumstances, clarifies that, for example, a priority area can be established only for a certain season. ${ }^{176}$ The new wording also serves the implementation of Art. 8 para. 1 of the MSP-Directive which makes reference to the temporal distribution of activities.

Being derived from terrestrial spatial planning, the rather static German marine spatial planning system seems ill-prepared for a shift towards innovative approaches of near real-time management that match the highly dynamic nature of marine ecosystems. ${ }^{177}$ There is, however, the possibility to constantly update planning stipulations through the incorporation by reference of the latest scientific findings, as long as the decision to do so is taken within the structured and collaborative spatial planning process. For example, the

173 Government of Canada, Fisheries and Ocean Canada, 'Hecate Strait / Queen Charlotte Sound Glass Sponge Reefs MPA' <www.dfo-mpo.gc.ca/oceans/mpa-zpm/hecate-eng .html $>$ accessed 30 September 2018.

174 Larry Crowder and Elliott Norse, 'Essential ecological insights for marine ecosystembased management and marine spatial planning' (2008) 32 Marine Policy 772, 774.

175 Cf. Commonwealth of Australia, Commonwealth marine environment report card, supporting the marine bioregional plan for the South-west Marine Region (2012) 24-25 $<$ www.environment.gov.au/system/files/pages/a73fb726-8572-4d64-9e33-1d32odd61ogc/ files/south-west-report-card-commonwealth.pdf >.

${ }_{17} 6$ Deutscher Bundestag, Draft Act amending the Federal Spatial Planning Act (document: Drucksache 18/10883, 2017) 11, 41.

177 Sara M Maxwell and others, 'Dynamic ocean management: Defining and conceptualizing real-time management of the ocean' (2015) 58 Marine Policy 42, 43. 
switch-off of wind turbines could be required in dependence on the latest data on bird migration. In that way, elements of dynamic management could be integrated into the spatial plan to keep up with the advances in data collection and sharing, particularly in remote sensing, animal tracking, and mobile technology. By increasing the speed at which scientific findings are implemented, this method can help to alleviate the disadvantages of the lengthy and complicated spatial planning process. To conclude, even though the German spatial planning tools have not been designed specifically for the purpose of applying an ecosystem approach, the FSPA largely provides for the possibility of both spatial and temporal adaptation of spatial planning measures to the needs of ecosystem protection.

Since marine ecosystems rarely have the character of an island but rather merge into each other, ${ }^{178}$ the design of spatial planning measures corresponding to ecosystem boundaries remains a challenging task. For ecosystem-based zoning, an orientation on existing recommendations for the design of networks of marine protected areas could be considered. For example, the recommendations to use complex site shapes, rather than simple rectangular boundaries or to establish 'mosaic' zones, ${ }^{179}$ could help to design priority or reserve areas whose boundaries relate closely to the features of an ecosystem. For spatially dynamic habitats such as sandbanks, boundaries could, where possible, encompass predicted changes in feature distribution to ensure their ongoing protection. ${ }^{180}$ Another difficulty in defining ecosystem boundaries stems from the variability of some ecosystem features. For example, an area in which a gyre enhances primary production or where fish forage cannot be mapped with the same precision as a sea-grass meadow or a reef. To cope with that difficulty, stable features important for ecosystem functioning could be accurately mapped and complemented by the mapping of the distribution of habitats on the bottom and the behavioural patterns of important species. ${ }^{181}$

${ }_{17} 8$ Rainer Holz, 'Ökologie, Naturschutz und Strategie: Der schwere Weg zur Integration' in Hermann Baier, Frithjof Erdmann, Rainer Holz and Arno Waterstraat (eds), Freiraum und Naturschutz (Springer-Verlag Berlin Heidelberg 2006) 283, 284.

179 Scottish Government / Scottish Natural Heritage / JNCC, Marine Protected Areas in Scotland's Seas (Guidelines on the selection of MPAs and development of the MPA network) $38<$ www.gov.scot/Resource/Doc/295194/0114024.pdf\#page=57\&zoom=auto,-79,482>.

180 Joint Nature Conservation Committee / Natural England, 'Marine Conservation Zone Project' (Ecological Network Guidance, 2010) 63 <http://jncc.defra.gov.uk/PDF/100705_ ENG_vio.pdf $>$.

181 Ferdinando Boero, 'From Marine Protected Areas to MPA Networks' in Paul Goriup (ed), Management of Marine Protected Areas: A Network Perspective (Wiley-Blackwell, 2017) 1, 13-14. 
The generation of such maps would constitute an important step forward with regard to ecosystem protection in the German marine spatial plans.

\subsection{Protection of Areas with Particular Significance for Ecosystem Functioning}

Protection of ecologically valuable areas plays a crucial role in the protection of ecosystems. In Germany, large parts of the coastal zone have already been protected through the establishment of Natura 2000 sites. On the coast of the North Sea, for example, the unique and largely untouched Wadden Sea is protected. Natura 2000 sites often overlap with areas protected by other national protection categories such as nature conservation areas, national parks, national nature monuments, biosphere reserves, landscape protection areas, nature parks, natural monuments, protected landscape elements and legally protected biotopes. ${ }^{182}$ Each of the national categories provides for a different degree of protection and for corresponding restrictions on anthropogenic activities. For example, in nature conservation areas, all actions which may lead to the destruction of, damage to, or changes in the area, or parts thereof, or which may cause permanent disturbance thereto, are prohibited. ${ }^{183}$ Within the territorial sea, spatial planning instruments are used as a complement to protect particularly vulnerable marine areas. In the State Spatial Development Programme of Mecklenburg-Western Pomerania, for example, Natura 2000 sites encompassing marine areas are planned to be established as reserve areas. ${ }^{184}$

In the EEZ, responsibility for Natura 2000 sites lies with the federal government. Germany notified the European Commission in 2004 of its nomination of ten Natura 2000 sites in the German EEz in the North Sea and the Baltic Sea. In September 2017, the ten sites were finally given protection at national level through six protected area regulations. ${ }^{185}$ The new protected areas cover approximately 30 percent of the German EEZ, ${ }^{186}$ which is in compliance with

182 Federal Agency for Nature Conservation, 'Map of protected areas in Germany' <www .geodienste.bfn.de/schutzgebiete> accessed 30 September 2018.

183 Section 23 para. 2 of the Nature Conservation Act.

184 Cf. Section 8.8 of the State Spatial Development Programme of Mecklenburg-Western Pomerania (LEP M-V 2016).

185 Federal Agency for Nature Conservation, 'Nationale Meeresschutzgebiete' <www.bfn .de/themen/meeresnaturschutz/nationale-meeresschutzgebiete.html> accessed 30 September 2018.

186 Federal Ministry for the Environment, Nature Conservation, Building and Nuclear Safety, 'Six new Marine Protected Areas in the North and Baltic Seas' (27.09.2017) <www.bmub .bund.de/en/pressrelease/sechs-neue-meeresnaturschutzgebiete-in-nord-und-ostsee/> accessed 30 September 2018. 
a recommendation issued in 2013 by the Scientific Advisory Board of the Federal Government for global environmental changes (WBGU) to protect 20-30 percent of the marine ecosystems. ${ }^{187}$ However, whereas in the spatial plans for the EEZ priority areas have been designated for shipping, pipelines and cables as well as for wind energy development and reserve areas have been designated for shipping, pipeline, and research uses, neither Natura 2000 sites nor other ecologically significant areas received any additional protection through spatial planning measures, as recommended, for example, in the planning contribution of the Federal Agency for Nature Conservation of 2006. ${ }^{188}$ Natura 2000 sites have rather only been listed for information. This approach is justified in the spatial plans as follows: 'European bird sanctuaries and areas listed under the Habitats Directive in the EEZ enjoy comprehensive protection under nature conservation law. Since these areas are of importance to overall spatial planning considerations, they have been included in the Spatial Plan for information in order to enable the spatial requirements of individual uses to be coordinated. Based on the environmental report, bird sanctuaries and the Sites of Community Importance in the EEz have been taken into account in the provisions of the Spatial Plan.' 189

In some source-related spatial planning measures, i.e. measures that regulate the conditions for specific uses, explicit reference is made to protected areas. For example, the section on pipelines and submarine cables requires that consideration is given to protected area designations when routeing pipelines and submarine cables. ${ }^{190}$ Furthermore, the plans stipulate that offshore wind turbines outside the designated priority areas are not allowed in Natura 2000 sites. Offshore wind farms already approved and those having reached an advanced stage in the approval procedure when the spatial plan entered into force are exempted from this regulation. ${ }^{191}$ In this way, about 28 percent of the German EEZ in the North Sea is kept free of offshore wind farms. ${ }^{192}$

187 WBGU, Wissenschaftlicher Beirat der Bundesregierung Globale Umweltveränderungen, Welt im Wandel Menschheitserbe Meer (2013) 291.

188 Cf. the recommendations in the planning contribution of the Federal Agency for Nature Conservation, Naturschutzfachlicher Planungsbeitrag des Bundesamtes für Naturschutz zur Aufstellung von Zielen und Grundsätzen der Raumordnung für die deutsche Ausschließliche Wirtschaftszone der Nord- und Ostsee (2006) 14 available online at <www.bfn .de/fileadmin/MDB/documents/themen/landschaftsplanung/Planungsbeitrag_zur_ Raumordnung_AWZ_20o6.pdf $>$.

189 Spatial Plan for the German Exclusive Economic Zone in the North Sea - Text section / unofficial translation / 3.7.2 Justification.

$190 \quad$ 3.3.1 Targets and principles, Principle 7.

191 Section 3.5 on energy production and wind energy in particular / Target 3.

192 Cf. justification to Target 3. 
In conclusion, the plans do not yet make full use of the possibilities that the FSPA offers to protect areas important for ecosystem functioning. For example, the management of protected areas could be supported by complementing spatial planning measures and the focus of protection broadened to include species and habitats not addressed by the current protected area regulations. ${ }^{193}$ Moreover, protection could be spatially expanded to include further functionally important areas such as areas important for key life cycle stages and behaviours, areas of high biodiversity and areas of high productivity. To identify additional areas that need to be protected by spatial planning measures, the scientific criteria adopted in 2008 by the ninth meeting of the Conference of the Parties to the Convention on Biological Diversity (COP 9) for the identification of Ecologically and Biologically Significant Areas (EBSAS) could be used. The criteria listed are: uniqueness or rarity; special importance for life history stages of species; importance for threatened, endangered or declining species and/or habitats; vulnerability, fragility, sensitivity or slow recovery; biological productivity; biological diversity; and naturalness. ${ }^{194}$ The procedure to identify EBSAS in the Baltic Sea is still in progress at this time, but HELCOM has already accepted the potential use of EBSAs as a basis for ecosystem-based MSP measures. ${ }^{195} \mathrm{~A}$ further possible approach is the protection of portions of marine space that are especially highly connected with each other ('Cells of Ecosystem Functioning'196) by corresponding spatial planning measures. The special connection may result from common climatic, biogeographic or oceanographic conditions. ${ }^{197}$ However, such 'Cells of Ecosystem Functioning' are difficult to sharply define. ${ }^{198}$

193 With the same aim, the programme of measures adopted in Germany to implement the MSFD provides for a new measure considering the inclusion of species and biotopes that define the value of an ecosystem in national protected area regulations (Environment Agency for the Federal Ministry of the Environment, Nature Conservation, Construction and Nuclear Safety, MSFD Programme of Measures for Marine Protection in the German Parts of the North Sea and the Baltic Sea, Report pursuant to Article 45h (1) of the Federal Water Act, English Summary, Annex 3).

194 Convention on Biological Diversity, Annex I, decision Ix/20, 'Background on the EBSA Process' <www.cbd.int/ebsa/about> accessed 30 September 2018.

195 HELCOM, Heads of Delegation, Identifying Ecologically or Biologically Significant Marine Areas (EBSAs) in the Baltic Sea (HOD 51-2016).

196 Ferdinando Boero, 'From Marine Protected Areas to MPA Networks' in Paul Goriup (ed), Management of Marine Protected Areas: A Network Perspective (Wiley-Blackwell, 2017) 1, 9.

197 Ibid., 8-9.

198 Ibid., 13. 


\subsection{Consideration of Connectivity}

The marine environment is ecologically connected through movements of species, nutrients and energy. ${ }^{199}$ This connectivity in marine systems operates at scales ranging from microns to thousands of kilometres. ${ }^{200}$ Connectivity can be defined either structurally or functionally. Structural connectivity refers to the spatial arrangement of specific features in the sea, whereas functional connectivity refers to the behaviour of species and ecological processes. ${ }^{201}$ The maintenance of connectivity in the marine area seems crucial for the protection of ecosystems.

With regard to connectivity, the FSPA states that the needs of the biotope network have to be considered in spatial planning. ${ }^{202}$ For example, Section 6.1 of the State Spatial Development Programme of Mecklenburg-Western Pomerania on environment and nature protection stipulates that, to promote biological diversity and ecosystems typical for the region, Natura 2000 sites and areas of the biotope network are to be connected (Principle 4). In contrast, the current marine spatial plans for the EEZ state that there has not yet been sufficient research into the extent that marine ecosystems, which are more permeable than terrestrial ecosystems and largely barrier-free, may be equally dependent on biotope networks to be defined in a spatial plan, and how possible components can be delineated. Therefore, detailed designations for a biotope network have not yet been possible. However, measures are required to be taken to ensure that dispersion processes and large-scale ecological interactions of species and habitats are taken into account at the approval level (cf. justification for the spatial planning regulations on exploitation of non-living resources / Section 3.2). In addition, according to Guideline 2.5, disruptions to and pollution of the marine ecosystem and the related natural functions, systems and processes are to be avoided and biological diversity promoted and preserved.

The establishment of networks of protected areas, which facilitate an undisturbed exchange of organisms and nutrients, is considered as an essential

\footnotetext{
199 Joint Nature Conservation Committee / Natural England, 'Marine Conservation Zone Project' (Ecological Network Guidance, 2010) $46<$ http://jncc.defra.gov.uk/PDF/100705_ ENG_vio.pdf>.

200 Melanie Bishop and others, 'Effects of ocean sprawl on ecological connectivity: impacts and solutions' (2017) 492 Journal of Experimental Marine Biology and Ecology 7, 9.

201 European Commission, DG Environment, The Multifunctionality of Green Infrastructure (2012) Science for Environment Policy $10<\mathrm{http}$ ://ec.europa.eu/environment/nature/ ecosystems/docs/Green_Infrastructure.pdf>.

202 Section 2 para. 2 no. 6 FSPA.
} 
element of ecosystem-based marine spatial planning. ${ }^{203}$ The importance of such networks is recognized by the EU ${ }^{204}$ as well as by OSPAR and HELCOM. ${ }^{205}$ Nevertheless, protected areas in Germany currently constitute 'islands of protection' rather than linked networks. Spatial planning measures could help form a network of protected areas by protecting the migration paths of certain species to connect their sub-habitats or scattered populations, or by connecting similar habitats to reinforce the respective protection effect. The degree of protection of the connecting areas, for example migration corridors or stepping stones, would have to be at least commensurate with the function they need to fulfil. ${ }^{206}$

In the programme of measures adopted in Germany to implement the MSFD, a new measure 'to protect migratory species in marine areas $\left(\mathrm{UZ}_{3}-02\right)$ ' refers explicitly to the process of spatial planning. It is planned to assess the possibility of including priority areas and reserve areas, following regional (for North and Baltic Seas) and national (between federal level and federal state level) coordination, which serve as migration corridors for migrating species between areas of ecological importance. Ideally these will form a habitat network in the sense of a coherent network of protected areas. ${ }^{207}$ There is therefore good reason to hope that the next generation of spatial plans will contain migration corridors and that protected areas will therefore be better connected.

203 PJS Jones, LM Lieberknecht and W Qiu, 'Marine spatial planning in reality: Introduction to case studies and discussion of findings' (2016) 71 Marine Policy 256, 262.

204 Cf. Art. 13 para. 4 of the Marine Strategy Framework Directive (2008/56/EC/MSFD), according to which the programmes of measures to achieve or maintain good environmental status shall include spatial protection measures, contributing to coherent and representative networks of marine protected areas. With regard to the qualification of marine spatial planning measures as 'spatial protection measures' within the meaning of the MSFD cf. Daniel Braun, 'MPAs as Spatial Protection Measures under the MSFD' in Paul Goriup (ed), Management of Marine Protected Areas: A Network Perspective (Wiley-Blackwell, 2017) 89, 97-98.

205 Cf. OSPAR Recommendation 2003/3 on a Network of Marine Protected Areas and HELсом Recommendation 35/1 on a System of Coastal and Marine Baltic Sea Protected Areas.

206 Eva Schachtner, 'Marine Protected Areas and Marine Spatial Planning, with Special Reference to the Black Sea' in Paul Goriup (ed), Management of Marine Protected Areas: A Network Perspective (Wiley-Blackwell, 2017) 207, 211.

207 German Environment Agency for the Federal Ministry of the Environment, Nature Conservation, Construction and Nuclear Safety, MSFD Programme of Measures for Marine Protection in the German Parts of the North Sea and the Baltic Sea, Report pursuant to Article $45 \mathrm{~h}(1)$ of the Federal Water Act, English Summary, Annex 3. 
A more comprehensive option for taking connectivity into account in marine spatial planning is to implement the idea of building a 'green infrastructure' in the sea, as promoted, inter alia, by the EU. ${ }^{208}$ Green infrastructure is 'a strategically planned network of natural and semi-natural areas with other environmental features designed and managed to deliver a wide range of ecosystem services.' ${ }^{209}$ The concept is aimed at performing four broad roles that seem to correspond to the holistic objectives of the ecosystem approach: protecting ecosystems state and biodiversity; improving ecosystem functioning and promoting ecosystem services; promoting societal wellbeing and health and supporting the development of a green economy; and sustainable land and water management. ${ }^{210}$

Green infrastructure features include Marine Protected Areas, areas of high value for biodiversity and ecosystem health outside protected areas, ecological corridors, stepping stones corridors and ecological buffer areas. ${ }^{211}$ HELCOM has emphasized the importance of the concept for marine spatial planning by stating that, through that concept, habitats and biotopes, as well as their interconnectivity and seasonal variability could be captured into spatial presentation. ${ }^{212}$ To ensure a comprehensive protection of the environment, it has further been recommended that the design of green infrastructure for purposes other than biodiversity should never entail negative trade-offs. In this regard, biodiversity has been considered the 'judge' playing a key role in navigating between bad, good and better choices. ${ }^{213}$ This recommendation seems also suitable to be applied within the balancing of interests in the spatial planning process in view of an efficient ecosystem protection.

The main problem with regard to the consideration of connectivity within marine spatial planning is that connectivity issues are still poorly understood and are difficult to take into account if a specific migration path of species between identified places is unknown. In the absence of detailed dispersal data, connectivity can only be approximated by ensuring protection of a well distributed space or by having recourse to general assumptions. For example,

208 European Commission, 'Green Infrastructure' < http://ec.europa.eu/environment/nature/ ecosystems/index_en.htm> accessed 30 September 2018.

209 Ibid.

210 European Commission, DG Environment, The Multifunctionality of Green Infrastructure (2012) Science for Environment Policy 1, 2.

211 Ibid., 6.

212 HELCOM, Heads of Delegation, Identifying Ecologically or Biologically Significant Marine Areas (EBSAs) in the Baltic Sea (HOD 51-2016).

213 European Commission, DG Environment, The Multifunctionality of Green Infrastructure, (2012) Science for Environment Policy 4. 
connectivity can be assumed to more often follow similar depth, temperature and salinity values than cross them or to follow the general paths of currents, eddies, and gyres. ${ }^{214}$ When designing spatial planning measures to ensure connectivity, care has furthermore to be taken that the different aspects of connectivity are taken into account and that the focus is not put on one element or one species to the detriment of others. ${ }^{215}$

\subsection{Protection of Open Space}

The viability of ecosystems decisively depends upon sufficient open space and unspoiled nature. ${ }^{216}$ If the critical parameters are left undisturbed, it is likely that a natural system will remain within its normal range of variation. ${ }^{217}$ In the face of the knowledge deficit with regard to connectivity, protecting an appropriate amount of open space appears to be, consistent with the precautionary principle, the best option to ensure ecosystem protection. The FSPA stipulates in this regard the principle that open space should be protected, fragmentation effects reduced and additional land use limited. ${ }^{218}$

To put this principle into more concrete terms, in the spatial plans, a guideline on long-term sustainable use of the properties and potential of the EEZ has been formulated that aims to preserve the sea as an area characterized by vastness, openness, and freedom from barriers (Guideline 2.4). The basic premise is that stationary uses must be reversible and can only be allowed for limited periods of time. Moreover, the available space should be used economically, for example, by promoting a combination of uses.

Details for the protection of open space are regulated under the individual activities. For example Section 3.2.1 on the exploitation of non-living resources provides that, to ensure an efficient use of space, the exploitation of raw material resources should be concentrated in an area and should be as small-scale as possible. Existing sand and gravel sites should be exploited to the maximum extent practicable. This only applies provided that it is compatible with marine environmental concerns and that a remaining sediment

214 OSPAR Commission, Background document to support the assessment of whether the OSPAR Network of Marine Protected Areas is ecologically coherent (Biodiversity Series, 2007) 30.

215 OSPAR, Guidance on Developing an Ecologically Coherent Network of OSPAR Marine Protected Areas (Reference number 2006-3) 20.

216 Ernst-Hasso Ritter, 'Freiraum / Freiraumschutz' in Akademie für Raumforschung und Landesplanung (ed), Handwörterbuch der Raumordnung (2005) 336, 336.

217 Parliamentary Commissioner for the Environment of New Zealand, Setting Course for a Sustainable Future: The Management of New Zealand's Marine Environment (1999) 56-57 $<$ www.pce.parliament.nz/media/pdfs/Sustainable_Future_report.pdf>.

218 Section 2 para. 2 no. 2 and no. 6 FSPA. 
layer, which is necessary for the recovery of benthic communities, is preserved (Principle 4). Furthermore, Principle 3 on the marine environment states that the seascape should be safeguarded in its natural character and its typical vast open spaces should be preserved. The large spaces of the EEZ should be permanently preserved, developed and safeguarded as an ecologically intact open space, acknowledging their importance to a functional seabed, the water budget, fauna and flora (biodiversity), and climate. Thus, the importance of the protection of open space has been recognized in the plan.

Even though those stipulations help to reduce impacts of ocean sprawl on connectivity and ecosystem functioning, ${ }^{219}$ they do not yet ensure that a certain absolute area is kept free from human activities. Such protection could be implemented by designating areas especially for the protection of processes and thus for the undisturbed development of nature. ${ }^{220}$ Such areas must be of sufficient size to enable processes relevant for the functioning of ecosystems to unfold. For the Wadden Sea, the tidal basin has been considered the smallest spatial unit which contains all relevant ecological subsystems, biotopes and habitats. ${ }^{21}$ As a further development, quantitative targets for the use of space could be set for the EEz.222 Through the new Section 2 para. 2 no. 6 of the FSPA, regional planning authorities are, for example, encouraged to set quantitative targets for the terrestrial area to support the goal of the federal government to reduce the new land use for human settlements and transport area to 30 hectares per day by $2020 .^{223}$

\section{6}

\section{Conclusion}

Even though the spatial plans for the German EEz state that they aim to promote the achievement of good environmental status in the marine environment, ${ }^{224}$ it is questionable to what extent they actually contribute to

\footnotetext{
219 Melanie Bishop and others, 'Effects of ocean sprawl on ecological connectivity: impacts and solutions' (2017) 492 Journal of Experimental Marine Biology and Ecology 7, 21-22.

220 Cf. for example Section 2.3 of the spatial planning contribution for biological diversity, Free State of Saxony (Agency for the Environment, Agriculture and Technology).

221 Behrends, Brigitte and others, 'Gesamtsynthese Ökosystemforschung Wattenmeer', (Umweltbundesamt, 2004) 419.

222 Klaus Einig and Margarete Spiecker, 'Die rechtliche Zulässigkeit regionalplanerischer Mengenziele zur Begrenzung des Siedlungs- und Verkehrsflächenwachstums' (Special Issue, 2002) Zeitschrift für Umweltrecht 150, 151.

223 Deutscher Bundestag, Draft Act amending the Federal Spatial Planning Act (document: Drucksache 18/10883, 2017) 9, 39 .

224 Guideline 2.5.
} 
the protection of marine ecosystems. As has been shown, the current plans do not make full use of the possibilities provided by the German regulatory framework to translate the demands of nature, and especially of ecosystem protection, into spatial planning measures. One reason for this is that, at the time the plans were adopted, it was not possible to completely assess the ecological state of the sea and the impacts of anthropogenic activities on the marine environment. ${ }^{225}$ It was therefore also considered not possible to comprehensively regulate those activities based on the needs of marine ecosystems. Completing the knowledge gaps on ecosystem functioning is a difficult and never-ending process. For the development of the next generation of plans, however, greater knowledge is already available. To cope with remaining knowledge gaps, a more courageous application of the precautionary principle can help to further put the ecosystem approach into practice.

In addition, the plans have been criticized for their predominantly descriptive character. ${ }^{226}$ The amended FSPA now explicitly encourages the adoption of planning provisions that not only protect, but also improve the marine environment. ${ }^{227}$ Compared to a mere protection, the requirement to use spatial planning provisions to improve the marine environment seems to constitute an important step towards a more proactive approach to the consideration of environmental concerns in marine spatial planning. It remains to be seen to what extent this requirement will be reflected in the future plans.

A further key challenge in Germany lies in the distribution of competences which conflicts with the holistic management required by the ecosystem approach. Firstly, there are differing competences for the conservation of the marine environment and marine spatial planning. Secondly, there are differing competences for spatial planning within the territorial sea and within the EEZ. The consequences of differing competences for nature conservation within the territorial sea and the EEZ are clearly visible with regard to the location and design of the German marine protected areas. Rather than building a coherent network, they seem to be scattered throughout the sea without previous thorough planning and coordination. As has been shown, spatial planning can help to complement and connect protected areas and to thereby multiply their effectiveness. Close cooperation with both the federal states and

225 Environmental Report for the Spatial Plan for the German EEZ of the North Sea (2009) 388.

226 Sachverständigenrat für Umweltfragen, 'Der Entwurf des deutschen Maßnahmenprogramms zum Schutz der Nord- und Ostsee' (Kommentar zur Umweltpolitik, 2015) 7 $<$ www.umweltrat.de/SharedDocs/Downloads/DE/05_Kommentare/2012_2016/2015_08_ KzU_15.pdf?_blob=publicationFile\&v $=3>$.

227 Section 17 para 1 FSPA, Art. 5 para 2 MSP-Directive. 
the neighbouring states is crucial for establishing such an effective network of marine protected areas across administrative boundaries and, beyond that, a coherent ecosystem-based management of the whole marine area.

Despite the above-described deficits, it cannot be determined that the spatial plans for the German EEZ have not followed the ecosystem approach. Already the legal requirements regarding the process of planning and the consideration of environmental concerns ensure that, at least to some extent, the plans have taken an ecosystem approach. The efficacy of an ecosystem approach can now be improved with each iteration of the plans: from basic considerations with limited benefits for the protection of marine ecosystems, to advanced approaches with extensive benefits. ${ }^{228}$ In Germany, particularly with regard to the actual ecosystem protection, there remains considerable scope for improvement. Notably, it does not appear sufficient to simply encourage other authorities to apply the ecosystem approach (cf. 3.7.1 Principles / Marine ecosystem) and to protect marine ecosystems. Important decisions rather have to be taken at the planning level to redress the balance in the sea in favour of ecosystem protection.

The MSP-Directive leaves a wide margin for the integration of environmental concerns into spatial planning. It only provides a framework for maritime spatial planning, while member states remain responsible and competent for designing and determining, within their marine waters, the format and content of such plans. ${ }^{229}$ Through their maritime spatial plans, member states shall aim to contribute to the preservation, protection and improvement of the environment, but also to the sustainable development of energy sectors at sea, of maritime transport, and of the fisheries and aquaculture sectors. ${ }^{230}$ How the different objectives are reflected and weighted in their maritime spatial plans is left to the member states. The mere obligation to establish marine spatial plans, however, does not yet guarantee the achievement of environmental objectives and should therefore not be considered as the ultimate goal. The goal should rather be to achieve real outcomes such as the conservation of marine ecosystems. ${ }^{231}$ Because of the weak European regulatory framework for marine spatial planning, the degree of progress in that regard depends

228 Scottish Natural Heritage, 'An ecosystem approach to marine planning - a summary of selected tools, examples \& guidance' (2016) <www.nature.scot/sites/default/files/2017 -06/2016\%2005\%2018\%20-\%2oEcosystem\%2oapproach\%2oin\%2omarine $\% 20$ planning\%20-\%2oFINAL\%2oVersion\%201.pdf> 1, 2.

229 Recital 11 of the MSP-Directive.

230 Art. 5 para 2 MSP-Directive.

231 Charles N. Ehler, 'Perspective: 13 Myths of Marine Spatial Planning' (2012) 5(5) Marine Ecosystems and Management 1, 1. 
decisively on the political will of the member states to assign to marine spatial planning not only a coordinating role between the different interests, but a steering role towards ecosystem-based management.

\section{Table of Authorities}

\section{Statutes and Statutory Instruments}

Environmental Impact Assessment Act of 24 February 2010 (Federal Law Gazette, Part I, No 7/94), last amended by the Act of 15 September 2017 (Federal Law Gazette, Part. 1 No 62/3370)

Federal Nature Conservation Act of 29 July 2009 (Federal Law Gazette, Part I, No 51/2542), last amended by the Act of 15 September 2017 (Federal Law Gazette, Part I, No 64/3434)

Federal Spatial Planning Act of 22 December 2008 (Federal Law Gazette, Part I, No 65/2986), last amended by the Act of 23 May 2017 (Federal Law Gazette, Part I, No $30 / 1245$ )

Nature and Landscape Conservation Act of the federal state Mecklenburg-Western Pomerania (LNatG M-V / GVOBl. M-V 2003/1)

Spatial Plan for the Baltic Sea (Annex to Federal Law Gazette, Part I, No 78 of 18 December 2009)

Spatial Plan for the North Sea (Annex to Federal Law Gazette, Part I, No 61 of 25 September 2009)

State Spatial Development Programme of Mecklenburg-Western Pomerania (LEP M-V 2016)

United Nations Convention on the Law of the Sea, 1833 UNTS 3; 21 ILM 1261 (1982)

\section{EU Legislation}

Directive 2000/6o/EC of the European Parliament and of the Council establishing a framework for community action in the field of water policy (Water Framework Directive) [2000] OJ L 327/1

Recommendation of the European Parliament and of the Council concerning the implementation of Integrated Coastal Zone Management in Europe [2002] OJ L $148 / 24$

Directive 2008/56/EC of the European Parliament and of the Council establishing a framework for community action in the field of marine environmental policy (Marine Strategy Framework Directive) [2008] OJ L 164/19

Directive 2014/89/EU of the European Parliament and of the Council establishing a framework for maritime spatial planning [2014] OJ L 257/135 
Cases

Niedersächsisches ovg (higher administrative court of Lower Saxony), decision of 28 October 2004, case number $1 \mathrm{KN} \mathrm{155/03}$ para 68

\section{Bibliography}

\section{Books}

Akademie für Raumforschung und Landesplanung, Maritime Raumordnung. Interessenlage, Rechtslage, Praxis, Fortentwicklung (2013) 1 Forschungsberichte der ARL.

Akademie für Raumforschung und Landesplanung, Nachhaltigkeitsprinzip in der Regionalplanung - Handreichung zur Operationalisierung (2000) Forschungs- und Sitzungsberichte vol 212.

Beaucamp, G, Das Konzept der zukunftsfähigen Entwicklung im Recht (Mohr Siebeck 2002).

Brandt, E and Runge, K, Kumulative und grenzüberschreitende Umweltwirkungen im Zusammenhang mit Offshore-Windparks (Nomos 2002).

Dressler and others, Weiterentwicklung der Landschaftsrahmenplanung und ihre Integration in die Regionalplanung (Landwirtschaftsverlag 2000) 29 Angewandte Landschaftsökologie.

Koch, H-J and Hendler, R, Baurecht, Raumordnungs- und Landesplanungsrecht (Boorberg 2015).

Spannowsky, W, Runkel, P and Goppel, K, ROG - Raumordnungsgesetz (Verlag C.H. Beck München 2010).

\section{Official Documents and Publications}

Black Sea Countries - Contracting Parties to the Bucharest Convention, Guideline on Integrated Coastal Zone Management in the Black Sea.

Commonwealth of Australia, Commonwealth marine environment report card, supporting the marine bioregional plan for the South-west Marine Region (2012) <www .environment.gov.au/system/files/pages/a73fb726-8572-4d64-9e33-1d32odd6109c/ files/south-west-report-card-commonwealth.pdf>.

Commission Decision (EU) 2017/848 laying down criteria and methodological standards on good environmental status of marine waters and specifications and standardised methods for monitoring and assessment, and repealing Decision 2010/477/EU [2017] OJ L 125.

Deutscher Bundestag, Draft Act amending the Federal Spatial Planning Act (document: Drucksache 18/10883, 2017).

Deutscher Bundestag, Draft Act amending the Federal Spatial Planning Act (document: Drucksache 16/10292, 2008). 
Deutscher Bundestag, Recommended Resolution and Report of the Committee for the Environment, Nature Conservation, Building and Nuclear Safety (document: Drucksache 18/12845, 2017).

Environment Agency for the Federal Ministry of the Environment, Nature Conservation, Construction and Nuclear Safety, MSFD Programme of Measures for Marine Protection in the German Parts of the North Sea and the Baltic Sea, Report pursuant to Article 45h (1) of the Federal Water Act, English Summary, Annex 3.

European Commission, DG Environment, The Multifunctionality of Green Infrastructure (2012) Science for Environment Policy 13. http://ec.europa.eu/environment/ nature/ecosystems/docs/Green_Infrastructure.pdf.

European Environment Agency, State of Europe's seas EEA (Report No 2/2015) 192.

Federal Agency for Nature Conservation, Naturschutzfachlicher Planungsbeitrag des Bundesamtes für Naturschutz zur Aufstellung von Zielen und Grundsätzen der Raumordnung für die deutsche Ausschließliche Wirtschaftszone der Nord- und Ostsee (2006) <www.bfn.de/fileadmin/MDB/documents/themen/landschaftsplanung/ Planungsbeitrag_zur_Raumordnung_AWZ_20o6.pdf $>$.

Federal Environment Agency, Report on the Implementation of Integrated Coastal Zone Management in Germany (National ICZM Report, 2011). <www.umweltbundesamt .de/sites/default/files/medien/371/publikationen/national_report_iczm_in_ germany.pdf $>$.

Federal Maritime and Hydrographic Agency, Non-technical summary of the Environmental Report for the North Sea.

Federal Maritime and Hydrographic Agency, Standard Investigation of the Impacts of Offshore Wind Turbines on the Marine Environment (StUK4) (2013) <www.bsh.de/ DE/PUBLIKATIONEN/_Anlagen/Downloads/Offshore/Standards-EN/Standard -Investigation-impacts-offshore-wind-turbines-marine-environment.pdf?_blob $=$ publicationFile $\& v=4>$.

Federal Ministry for the Environment, Natures Conservation and Nuclear Safety, Integrated Coastal Zone Management in Germany - Assessment and steps towards a national ICZM strategy (March 2006) <www.ikzm-strategie.de/dokumente/ikzm_ englisch_final.pdf $>$.

Federal Ministry for the Environment, Natures Conservation and Nuclear Safety, Nationale Strategie für ein integriertes Küstenzonenmanagement (Cabinet Decision of 22 March 2006).

Federal State Parliament of Mecklenburg-Western Pomerania (document: Drucksache 6/3237 of 30 September 2014).

HELCOM, Heads of Delegation, Guideline for the implementation of ecosystem-based approach in Maritime Spatial Planning (MSP) in the Baltic Sea area (EBA-Guideline) (HOD 50-2016).

HELCOM, Heads of Delegation, Identifying Ecologically or Biologically Significant Marine Areas (EBSAs) in the Baltic Sea (HOD 51-2016). 
HelCom Recommendation 35/1 on a System of Coastal and Marine Baltic Sea Protected Areas.

HELCOM / Ospar Commission for the Protection of the Marine Environment of the North East Atlantic, Statement, Towards an Ecosystem Approach to the Management of Human Activities (First Joint Ministerial Meeting of the HELSINKI and OSPAR Commissions, 2003).

H ELCOM / VASAB, Country Fiche - Germany (updated November 2016) < www.helcom .fi/Documents/Action\%2oareas/Maritime\%2ospatial\%2oplanning/Country\%20 fiche_DE_Nov2016.pdf $>$.

H ELCOM / VASAB, Guidelines on transboundary consultations, public participation and co-operation, adopted by the 72nd meeting of VASAB CSPD/BSR on 8 June 2016 and approved by HELCOM HOD 50-2016 on 15-16 June 2016.

OSPAR Commission, Background document to support the assessment of whether the OSPAR Network of Marine Protected Areas is ecologically coherent (Biodiversity Series, 2007).

OSPAR, Guidance on Developing an Ecologically Coherent Network of OSPAR Marine Protected Areas (Reference number 2006-3).

OSPAR Recommendation 2003/3 on a Network of Marine Protected Areas.

Parliamentary Commissioner for the Environment of New Zealand, Setting Course for a Sustainable Future: The Management of New Zealand's Marine Environment (1999). $<$ www.pce.parliament.nz/media/pdfs/Sustainable_Future_report.pdf >.

Scottish Government / Scottish Natural Heritage / JNCC, Marine Protected Areas in Scotland's Seas (Guidelines on the selection of MPAs and development of the MPA network) <www.gov.scot $/$ Resource $/$ Doc $/ 295194 /$ o114024.pdf $\#$ page $=57 \&$ zoom $=$ auto,-79,482>.

United Nations, Johannesburg Declaration on Sustainable Development, World Summit on Sustainable Development, A/CoNF.199/20, Chapter 1, Resolution 1, Johannesburg (September 2002).

World Commission on Environment and Development, Our Common Future (Brundtland Report 1987).

\section{Book Chapters}

Boero, F, 'From Marine Protected Areas to MPA Networks' in Paul Goriup (ed), Management of Marine Protected Areas: A Network Perspective (Wiley-Blackwell, 2017) 1.

Braun, D, 'MPAs as Spatial Protection Measures under the MSFD', in Paul Goriup (ed), Management of Marine Protected Areas: A Network Perspective (Wiley-Blackwell, 2017) 89 .

Brunnée, J and Toope, SJ, 'Environmental Security and Freshwater Resources: A Case for International Ecosystem Law' in Handl (ed), 5 Yearbook of International Environmental Law (Oxford University Press 1994) 41. 
Bunge, T, 'Möglichkeiten und Grenzen der „Abschichtung“ bei der strategischen Umweltprüfung' in Dieter Eberle and Christian Jacoby (eds), Umweltprüfung für Regionalpläne (Akademie für Raumforschung und Landesplanung 2003) 20.

Czybulka, D, 'Der Ökosystemansatz als Managementprinzip des Naturschutzes', in Lothar Knopp and Heinrich Amadeus Wolff (eds), Umwelt - Hochschule - Staat: Festschrift für Franz-Joseph Peine zum 70. Geburtstag (Duncker \& Humblot 2016) 21.

Ehlers, P, 'Nutzungsregime in der Ausschließlichen Wirtschaftszone' in Peter Ehlers and Wilfried Erbguth (eds), Nutzungs- und Schutzkonflikte in der Ausschließlichen Wirtschaftszone (Nomos 2005) 13.

Holz, R, 'Ökologie, Naturschutz und Strategie: Der schwere Weg zur Integration' in Hermann Baier, Frithjof Erdmann, Rainer Holz and Arno Waterstraat (eds), Freiraum und Naturschutz (Springer-Verlag Berlin Heidelberg 2006) 283.

Hui, C, 'Carrying Capacity of the Environment' in James D Wright (ed), International Encyclopedia of the Social \& Behavioral Sciences (Elsevier 2015, 2nd edn) 155.

Ritter, E-H, 'Freiraum / Freiraumschutz' in Akademie für Raumforschung und Landesplanung (ed), Handwörterbuch der Raumordnung (2005) 336.

Sardá, R and others, 'Ecosystem-Based Management for Marine Protected Areas: A Systematic Approach' in Paul Goriup (ed), Management of Marine Protected Areas: A Network Perspective (Wiley-Blackwell, 2017) 145.

Schachtner, E, 'Marine Protected Areas and Marine Spatial Planning, with Special Reference to the Black Sea' in Paul Goriup (ed), Management of Marine Protected Areas: A Network Perspective (Wiley-Blackwell, 2017) 207.

Schmidt, C, 'Umweltprüfung und FFH-Verträglichkeitsprüfung von Raumordnungsplänen' in Dieter Eberle and Christian Jacoby (eds), Umweltprüfung für Regionalpläne (Akademie für Raumforschung und Landesplanung 2003) 56 .

Schubert, M, 'Meeresraumordnung und Europarecht: Die Richtlinie 2014/89/EU zur Schaffung eines Rahmens für die maritime Raumplanung', in Timo Hebeler (ed), Jahrbuch des Umwelt- und Technikrechts (2015) 199.

Stüer, B and Hönig, D, 'Raumordnung und Fachplanung im Widerstreit' in Jan Ziekow (ed), Bewertung von Fluglärm - Regionalplanung - Planfeststellungsverfahren (Duncker \& Humblot 2003) 225.

Turowski, G, 'Raumplanung' in Akademie für Raumforschung und Landesplanung (ed), Handwörterbuch der Raumordnung (2005) 893.

\section{Journal Articles}

Bishop, M and others, 'Effects of ocean sprawl on ecological connectivity: impacts and solutions' (2017) 492 Journal of Experimental Marine Biology and Ecology 7.

Crowder, L and Norse, E, 'Essential ecological insights for marine ecosystem-based management and marine spatial planning' (2008) 32 Marine Policy 772.

De Santo, EM, 'Environmental justice implications of Maritime Spatial Planning in the European Union' (2011) 35 Marine Policy 34. 
Douvere, $\mathrm{F}$, 'The importance of marine spatial planning in advancing ecosystem-based sea use management' (2008) 32 Marine Policy 762.

Ehler, CN, 'Perspective: 13 Myths of Marine Spatial Planning' (2012) 5(5) Marine Ecosystems and Management 1.

Einig, K and Spiecker, M, 'Die rechtliche Zulässigkeit regionalplanerischer Mengenziele zur Begrenzung des Siedlungs- und Verkehrsflächenwachstums' (Special Issue, 2002) Zeitschrift für Umweltrecht 150.

Jones, PJS, Lieberknecht, LM and Qiu, W, 'Marine spatial planning in reality: Introduction to case studies and discussion of findings' (2016) 71 Marine Policy 256.

Kment, M, 'Standortfestlegungen und Streckenverläufe - Neues zum Verhältnis von Raumordnung und Fachplanung' (Issue 6, 2010) 32 Natur und Recht 392.

Kühling, W and Hildmann, C, 'Umweltziele koordinieren und verbindlich machen' (2003) 107 RaumPlanung 62.

Long, RD, Charles, A and Stephenson, RL, 'Key principles of marine ecosystem-based management', (2015) 57 Marine Policy 53.

Maxwell, SM and others, 'Dynamic ocean management: Defining and conceptualizing real-time management of the ocean' (2015) 58 Marine Policy 42.

Merrie, A and Olsson, $\mathrm{P}$, 'An innovation and agency perspective on the emergence and spread of Marine Spatial Planning' (2014) 44 Marine Policy 366.

Nicolai, H von, 'Rechtliche Aspekte einer Raumordnung auf dem Meer', (2004) 7/8 Informationen zur Raumentwicklung 491.

Qiu, W and Jones, PJS, 'The emerging policy landscape for marine spatial planning in Europe', (2003) 39 Marine Policy 182.

Quiggin, J, 'Complexity, climate change and the precautionary principle' (2007) 7(3) Environmental Health 15 .

Spalding, MD and others, 'Marine Ecoregions of the World: A Bioregionalization of Coastal and Shelf Areas' (2007) 57(7) BioScience 573.

Van den Belt, H, 'Debating the Precautionary Principle: 'Guilty until Proven Innocent' or 'Innocent until Proven Guilty'?' (2003) 132 Plant Physiology 1122.

\section{Other Sources}

Baltic SCOPE, 'Recommendations on Maritime Spatial Planning Across Borders' (2017) Recommendation No. 5 on environment <www.balticscope.eu/content/ uploads/2015/07/BalticScope_OverallRecomendations_EN_WWW.pdf >.

Behrends, Brigitte and others, 'Gesamtsynthese Ökosystemforschung Wattenmeer', (Umweltbundesamt 2004).

Cooney, R, "The Precautionary Principle in Biodiversity Conservation and Natural Resource Management' IUCN Policy and Global Change Series no 2 (2004).

Garcia, SM and others, 'The ecosystem approach to fisheries' FAO Fisheries Technical Paper no 443 (2003) <www.fao.org/3/a-y4773e.pdf>. 
Joint Nature Conservation Committee / Natural England, 'Marine Conservation Zone Project' (Ecological Network Guidance, 2010) <http://jncc.defra.gov.uk/ PDF/100705_ENG_vio.pdf >.

Köppel, J, Wende, W and Herberg, A, 'Naturschutzfachliche und naturschutzrechtliche Anforderungen im Gefolge der Ausdehnung des Raumordnungsregimes auf die deutsche Ausschließliche Wirtschaftszone' [2006] Schriften des Bundesamtes für Naturschutz.

Robers, T, 'Das Gebot der nachhaltigen Entwicklung als Leitvorstellung des Raumordnungs- und Bauplanungsrechts' (2003) 209 Beiträge zur Raumplanung und zum Siedlungs- und Wohnungswesen.

Sachverständigenrat für Umweltfragen, 'Der Entwurf des deutschen Maßnahmenprogramms zum Schutz der Nord- und Ostsee' (Kommentar zur Umweltpolitik, 2015) $<$ www.umweltrat.de/SharedDocs/Downloads/DE/05_Kommentare/2012_2016/ 2015_08_KzU_15.pdf?_blob=publicationFile\&v=3>.

Sachverständigenrat für Umweltfragen, 'Meeresumweltschutz für Nord- und Ostsee' (Sondergutachten 2004) <www.umweltrat.de/SharedDocs/Downloads/DE/o2_ Sondergutachten/2004_SG_Meeresumweltschutz_fuer_Nord_und_Ostsee.pdf?_ blob=publicationFile $>$.

Schernewski, G, 'Integrated Coastal Zone Management (ICZM): From European strategy to practice in Germany' (2002) European Union for Coastal Conservation (EUCC) < http://eucc-d-inline.databases.eucc-d.de/files/documents/ooooo68o_ Schernewski_ICZM_Germany.pdf $>$.

Scottish Natural Heritage, 'An ecosystem approach to marine planning - a summary of selected tools, examples \& guidance' (2016) <www.nature.scot/sites/default/ files/2017-06/2016\%2005\%2018\%20-\%2oEcosystem\%2oapproach\%2oin\%2o marine\%2oplanning\%20-\%2oFINAL\%2oVersion\%201.pdf>.

Schultz-Zehden, A, Gee, K and Scibior, K, 'Handbook on Integrated Maritime Spatial Planning' (INTERReg III B CADSEs PlanCoast Project, 2008) < www.plancoast.eu/ files/handbook_web.pdf >.

Tegner Anker, H, presentation on 'Ecosystem perspectives in planning for offshore wind energy projects - does participation matter?', Conference The Ecosystem Approach in Ocean Planning and Governance (University of Gothenburg, 2016).

WBGU, Wissenschaftlicher Beirat der Bundesregierung Globale Umweltveränderungen, 'Welt im Wandel Menschheitserbe Meer' (2013).

\section{Online Sources}

Australian Government, Great Barrier Reef Marine Park Authority, 'About Zoning' <www.gbrmpa.gov.au/zoning-permits-and-plans/zoning/about-zoning> accessed 30 September 2018. 
Biodiversity Information Service System for Europe, 'Indicators for ecosystem services' <http://biodiversity.europa.eu/maes/mapping-ecosystems/indicators-for -ecosystem-services-marine $>$ accessed 30 September 2018.

Bundeszentrale für politische Bildung, 'Siedlungsstruktur und Bevölkerungsdichte' $<$ www.bpb.de/nachschlagen/datenreport-2016/226681/siedlungsstruktur-und -bevoelkerungsdichte $>$ accessed 30 September 2018.

BWE (Bundesverband WindEnergie), 'Offshore' <www.wind-energie.de/themen/ offshore $>$ accessed 30 September 2018.

Convention on Biological Diversity, Annex I, decision Ix/20, 'Background on the EBSA Process' < www.cbd.int/ebsa/about> accessed 30 September 2018.

Convention on Biological Diversity, 'Ecosystem Approach' < www.cbd.int/ecosystem/> accessed 30 September 2018.

Convention on Biological Diversity, COP 5 Decision v/6, 'Ecosystem Approach' < https:// www.cbd.int/decision/cop/?id=7148 > accessed 30 September 2018.

EUCC - Die Küstenunion Deutschland e.V., 'Die Ostseeküste' <www.ikzm-d.de/inhalt .php?page $=151,3494>$ accessed 30 September 2018.

European Commission, 'Green Infrastructure' <http://ec.europa.eu/environment/ nature/ecosystems/index_en.htm> accessed 30 September 2018.

Government of Canada, Fisheries and Ocean Canada, 'Hecate Strait / Queen Charlotte Sound Glass Sponge Reefs MPA' <www.dfo-mpo.gc.ca/oceans/mpa-zpm/hecate -eng.html $>$ accessed 30 September 2018.

Federal Agency for Nature Conservation, 'Map of protected areas in Germany' <www .geodienste.bfn.de/schutzgebiete> accessed 30 September 2018.

Federal Agency for Nature Conservation, 'Nationale Meeresschutzgebiete' <www.bfn .de/themen/meeresnaturschutz/nationale-meeresschutzgebiete.html $>$ accessed 30 September 2018.

Federal Ministry for the Environment, Nature Conservation, Building and Nuclear Safety, 'Six new Marine Protected Areas in the North and Baltic Seas' (27.09.2017). $<$ www.bmub.bund.de/en/pressrelease/sechs-neue-meeresnaturschutzgebiete-in -nord-und-ostsee/> accessed 30 September 2018.

Oxford Living Dictionaries, 'analysis paralysis' <https://en.oxforddictionaries.com/ definition/analysis_paralysis $>$ accessed 30 September 2018.

Statista, 'Anzahl der Personen in Deutschland, die in den vergangenen 12 Monaten an die Ostsee in den Urlaub gefahren sind' < https://de.statista.com/statistik/daten/ studie/173279/umfrage/beliebte-reiseziele---anzahl-der-ostseeurlauber/> accessed 30 September 2018.

Statista, 'Top 10 Seehäfen in Deutschland' <https:/de.statista.com/statistik/daten/ studie/239221/umfrage/groesste-haefen-in-deutschland-nach-gueterumschlag/> accessed 30 September 2018.

US National Oceanic and Atmospheric Administration (NOAA), 'Ecosystem Science' $<$ www.st.nmfs.noaa.gov/ecosystems/lme/index> accessed 30 September 2018. 